\title{
PENGARUH STRATEGI PEMECAHAN MASALAH DAN PEMAHAMAN BUDAYA TERHADAP PARTISIPASI MASYARAKAT DALAM PELESTARIAN KAWASAN LINDUNG TROWULAN, MOJOKERTO
}

\author{
Studi Eksperimen pada masyarakat Trowulan \\ Kresno Yulianto \\ Dosen Departemen Arkeologi Fakultas Ilmu Pengetahuan Budaya Universitas Indonesia
}

\begin{abstract}
A lot of damage due to excessive exploitation has been done on the prominent archaeological site of Trowulan, and this may partly be attributable to the minimum involvement of the community in the conservation efforts. The experimental study aims to assess the different effects of the two community- based conservation methods-Participation Rural Appraisal (PRA) and Rapid Rural Appraisal (RRA)—on the community participation in the preservation of the site. Four questions were raised as to (1) whether there is any difference between the participation of the community applying the PRA method and that of the community applying the RRA method; (2) whether there is any difference between the participation of the community with high level cultural understanding applying the PRA method and that of the community with high level cultural understanding applying the RRA method; (3) whether there is any difference between the participation of the community with low level cultural understanding applying the PRA method and that of the community with low level cultural understanding applying the RRA method; and (4) whether there is any interaction between problem solving strategy and cultural understanding in the participation of the community in the conservation of the Trowulan archaeological site. The $2 \times 2$ factorial design was applied on a sample consisting of 60 randomly selected adult and married respondents from two villages in Kecamatan Trowulan. The study found (1) a significant difference between the participation of the community applying the PRA method and that of the community applying the RRA method; (2) no difference between the participation of the community with high level cultural understanding applying the PRA method and that of the community with high level cultural understanding applying the RRA method; (3) no difference between the participation of the community with low level cultural understanding applying the PRA method and that of the community with low level cultural understanding applying the RRA method; and (4) interaction between problem solving strategy and cultural understanding in the participation of the community in the conservation of the Trowulan archaeological site.
\end{abstract}

\section{PENDAHULUAN}

Pembangunan berkelangsungan di Indonesia telah dicanangkan dalam program dan strategi pengelolaan lingkungan sebagaimana tertuang dalam dokumen Agenda 21 Indonesia. Hal ini merupakan penjabaran lebih lanjut Agenda 21 yang dihasilkan dalam Konferensi United Nation Conference on Environment and Development (Earth Summit) di Rio de Janeiro tahun 1992, Agenda 21 Indonesia merumuskan strategi nasional untuk kelangsungan pembangunan yang dikelompokkan menjadi empat bab yakni (1) pelayanan masyarakat, (2) pengelolaan sisa sumber daya, (3) pengelolaan sumber daya tanah, dan (4) pengelolaan sumber daya alam. Dari keempat bab tersebut, pengelolaan sumber daya tanah dipilih sebagai topik kajian ini.

Tanah adalah salah satu unsur bumi, yang bersama dengan unsur bumi yang lain yaitu air alami dan atmosfer, menjadi inti fungsi, perubahan, dan kemantapan ekosistem. Tanah berkedudukan secara khas dalam masalah lingkungan hidup yakni membentuk landasan hakiki bagi kehidupan manusia. Fungsi-fungsi vital tanah dalam ekosistem mencakup (1) kelangsungan kegiatan, keanekaan, dan produktivitas hayati, (2) mengatur dan membagi-bagi aliran air dan larutan, (3) menyaring, menyangga, mengelola bahan-bahan organik dan anorganik, (4) menyimpan dan mendaurkan hara, dan (5) memberikan topangan bagi bangunan sosio-ekonomi dan perlindungan bagi khasanah arkeologik yang berhubungan dengan permukiman manusia (Allan, 1995:14).

Untuk menjaga kelangsungan peri kehidupan dan meningkatkan kesejahteraannya, manusia tidak mungkin mengabaikan upaya mencegah degradasi berbagai fungsi tanah. Harus disadari bahwa degradasi fungsi tanah itu sendiri merupakan bagian dari indikator fisik proses penggurunan. Dengan demikian menjadi makin jelas bahwa tanah merupakan komponen lingkungan hidup yang secara mutlak harus dilindungi atau dihindarkan dari dampak yang merugikan. Konservasi tanah dan lingkungan - tidak bisa tidak - merupakan suatu

\begin{tabular}{|l|c|c|c|}
\hline Volume XI & Nomor 02 & Maret 2010 & ISSN 1411-1829 \\
\hline
\end{tabular}


keharusan untuk mengelola lingkungan agar dapat dihuni manusia dan mahluk lain (Barrow, 1995:108).

Pengelolaan sumber daya tanah dipandang penting dan didasari oleh pertimbangan bahwa proses-proses pembangunan yang akan terjadi di Indonesia masih akan ditumpukan pada potensi sumber daya tanah. Oleh karena itu sumber daya tanah dengan segala komponen yang ada di dalamnya termasuk air, biota, dan lainnya harus dikelola secara baik. Empat hal penting perlu dicatat dalam hal ini.

Pertama, adalah pemikiran bahwa oleh karena krisis ekonomi yang berkepanjangan serta runtuhnya unit-unit industri yang mengandalkan bahan baku impor, proses-proses eksploitasi sumber daya tanah di Indonesia akan makin meningkat. Kedua, yang penting adalah bahwa berbagai upaya pengelolaan sumber daya tanah harus dilakukan secara terpadu. Ini berarti bahwa pengelolaan empat aspek (sumber daya tanah, hutan, pertanian, dan sumber daya air) tidak boleh dilakukan secara parsial oleh karena keterkaitan yang erat di antaranya. Ke-tiga, dalam pengelolaan sumber daya tanah menyangkut fakta bahwa setiap daerah di Indonesia mempunyai tingkat persoalan yang berbeda, sehingga pilihan-pilihan pengelolaannya juga dapat berbeda. Konsekuensinya adalah bahwa setiap pemerintah daerah harus secara inovatif merumuskan bentuk-bentuk pilihan pengelolaan lingkungan yang sesuai dengan kondisi dan persoalan di daerah masing-masing. Terakhir, perlu dicatat bahwa berbagai upaya pengelolaan sumber daya tanah akan berkaitan dengan prosesproses penataan dan perijinan ruang sebagaimana telah diatur dalam Undang-undang tentang Penataan Ruang No. 24 tahun 1992.

Salah satu sumber daya tanah yang diatur dalam undang-undang ini adalah Kawasan Lindung. Menurut Undang-undang Republik Indonesia Nomor 24 tahun 1992 tentang Penataan Ruang, yang dimaksud dengan Kawasan Lindung adalah kawasan yang ditetapkan dengan fungsi utama melindungi kelestarian lingkungan hidup yang mencakup sumber daya alam dan sumber daya buatan (Tunggal, 2001:60-102). Kelestarian lingkungan hidup mencakup pula sumber daya alam dan sumber daya buatan yang mempunyai nilai sejarah dan budaya bangsa. Sebelumnya, yakni tahun 1990 dalam Keputusan Presiden Republik Indonesia nomor 32 tahun 1990 tentang Pengelolaan Kawasan Lindung juga dinyatakan bahwa Kawasan Lindung adalah kawasan yang ditetapkan dengan fungsi utama melindungi kelestarian lingkungan hidup yang mencakup sumber daya alam, sumber daya buatan dan nilai sejarah serta budaya bangsa guna kepentingan pembangunan berkelangsungan. Berbagai kegiatan yang mengganggu fungsi lindung pada dasarnya dilarang terutama apabila terjadi perubahan bentang alam, kemunduran kondisi penggunaan lahan serta perubahan ekosistem alami semula, karena berbagai perubahan betapapun kecilnya sebagai dampak kegiatan pasti akan terjadi. Apabila ada berbagai kegiatan di Kawasan Lindung yang menimbulkan dampak penting terhadap lingkungan hidup, maka perlu dikenakan ketentuan sebagaimana terdapat dalam PP No. 27 tahun 1999 tentang Analisis Mengenai Dampak Lingkungan. Berbagai kegiatan budi daya yang mungkin harus/terpaksa dilakukan di Kawasan Lindung harus tetap memperhatikan fungsi Kawasan Lindung itu, misalnya:

(a) Eksploitasi mineral dan air tanah, hal mana berada di bawah kepentingan sektor pertambangan dan pekerjaan umum/pertanian/perindustrian/dalam negeri.

(b) Eksploitasi mineral seperti batu bara, emas atau air tanah yang diperlukan untuk pembangunan, perlu memperhatikan berbagai ketentuan peraturan perundang-undangan yang berlaku untuk mendapatkan izin yang diperlukan.

(c) Kegiatan apa pun yang dilakukan di Kawasan Lindung, harus diikuti dengan upaya rehabilitasi ekosistem untuk dapat tetap berfungsi walaupun lain dari fungsinya semula asalkan memberi makna cukup baik bagi kehidupan dan bagi kemanusiaan khususnya. Untuk itu perlu diperhatikan bahwa rehabilitasi ekosistem sering kali tidak memungkinkan untuk 100\% dikembalikan kepada keadaan semula. Dalam keadaan di mana budi daya harus dilaksanakan di Kawasan Lindung, tanggung jawab berada dalam kebijaksanaan menteri yang berwenang, misalnya Menteri Pertambangan yang perlu mengaturnya dengan pertimbangan Badan Koordinasi Pengeloaan Tata Ruang Nasional (Soerjani, 2002:13).

Pentingnya pelestarian terhadap kawasan yang mengandung nilai sejarah serta budaya ini juga dinyatakan secara tegas dalam Piagam Burra (Burra Charter). Piagam Burra memberi panduan untuk konservasi dan pengelolaan tempat-tempat berciri budaya (tempat-tempat warisan budaya). Piagam ini menetapkan standar pelaksanaan bagi pihak-pihak yang memberikan saran, membuat keputusan, atau menangani pekerjaan pada tempat-tempat yang mengandung warisan budaya, termasuk pemilik, pengelola dan pengawas. Salah satu pasalnya, yakni pasal 12 bahkan secara eksplisit menyatakan bahwa pelestarian harus memberi tempat pada partisipasi orang-orang yang memiliki hubungan emosional dan makna khusus terhadap tempat tersebut atau orang- 
orang yang memiliki tanggung jawab sosial, spiritual atau budaya pada tempat tersebut (Anon, 1979:35).

Penelitian ini berkaitan dengan Kawasan Lindung yang memiliki nilai sejarah serta budaya bangsa yakni situs Trowulan. Pengertian Situs menurut Sharer dan Ashmore adalah lokasi yang mengandung atau diduga mengandung benda cagar budaya (data arkeologi dan sejarah) termasuk lingkungannya yang diperlukan bagi pengamanannya (Sharrer, 1980:82). Selanjutnya, menurut Mundardjito dalam ilmu arkeologi dikenal berbagai jenis situs (berdasarkan fungsi, waktu, ukuran, dan lokasinya), antara lain situs kota, situs keraton, situs perburuan, situs pantai, situs agama, situs makam (Mundardjito, 1986:26).

Situs Trowulan termasuk dalam wilayah administratif Kecamatan Trowulan dan Kecamatan Sooko, Kabupaten Mojokerto, Provinsi Jawa Timur. Letaknya kira-kira $10 \mathrm{~km}$ sebelah Tenggara Kota Mojokerto atau $55 \mathrm{~km}$ di sebelah barat daya Kota Surabaya. Situs tersebut dianggap sebagai pusat Kerajaan Majapahit yang pernah memegang peranan penting dalam sejarah Indonesia.

Situs ini digolongkan sebagai situs kota (townsite, city-site, atau urban-site), karena di situs ini ditemukan peninggalan purbakala dalam jumlah yang amat besar, jenis temuan yang aneka ragam, dan persebarannya yang luas sekali. Situs ini tersebar pada lima buah desa yakni Desa Trowulan, Desa Sentonorejo, Desa Temon, Desa Jatipasar dan Desa Bejijong.

Situs perkotaan kuno Trowulan kondisi alamnya tidak saja bernilai ekonomi tetapi juga mengandung arti sejarah dan budaya. Dengan demikian Situs Trowulan dapat dinyatakan sebagai Kawasan Lindung. Sebagai Kawasan Lindung yang di dalamnya terdapat sumber daya budaya, situs Trowulan perlu dikelola secara bijak agar berkelangsungan (sustainable) sehingga dapat dimanfaatkan secara optimal untuk masyarakat luas (Hardjasoemantri, 1997:17). Melalui ketiga perangkat undang-undang (Penataan Ruang, Pengelolaan Kawasan Lindung dan Burra Charter) nampak jelas diperlukannya kegiatan pelestarian, baik menyangkut sumber daya alam maupun sumber daya buatan.

Sebagai situs kota, daerah Trowulan meninggalkan kepada kita bukti-bukti budaya masa lampau dalam jumlah besar dan bervariasi banyak. Namun sangat disayangkan penduduk yang tinggal di sekitar situs Trowulan umumnya kurang peduli terhadap warisan budaya masa lampau. Kekurangpedulian tersebut antara lain nampak dari perusakan situs yang dilakukan oleh penduduk setempat. Bersamaan dengan giatnya penelitian tahun 1970-an, muncul masalah yang berkaitan dengan pelestarian peninggalan sejarah sekaligus tata lingkungannya. Sebagian besar sumur, sebagian besar tembok bata, sebagian besar temuan penting lainnya kini hancur oleh kegiatan manusia pembuat bata yang berlangsung terus sejak lama hingga sekarang. Tercatat sekurangnya 3000-an industri bata yang kini tersebar di situs Trowulan (Mundardjito, 2003:16). Padatnya penduduk yang menghuni situs menyebabkan perusakan situs di berbagai tempat yang pada awalnya disebabkan oleh eksploitasi lingkungan dalam berbagai wujud. Eksploitasi lingkungan tersebut antara lain berupa:

a. penggalian tanah untuk memperoleh lempung guna dijadikan bahan pembuat bata baru.

b. penggalian tanah untuk mendapatkan bahan bangunan berupa pasir dan kerikil yang terdapat pada posisi deposit yang lebih dalam.

c. penggalian tanah untuk memperoleh logam mulia dengan cara menyaring.

d. penggalian tanah untuk memperoleh bata kuno yang akan dijual ke pabrik semen merah.

Dalam konteks ini, upaya pelestarian menjadi makin penting untuk dilakukan. Upaya perlindungan sebagai bagian dari pelestarian tinggalan arkeologi di Indonesia sebenarnya telah cukup lama dilakukan melalui perangkat peraturan formal, seperti Lembaran Negara No. 238 tahun 1931 yang dikenal dengan Monumenten Ordonnantie (MO). Kemudian, dikeluarkan Peraturan Pemerintah (PP) No. 29 tahun 1986 tentang Analisis Mengenai Dampak Lingkungan (Amdal) yang kemudian dijabarkan dalam Keputusan Menteri Negara Kependudukan dan Lingkungan Hidup (KLH) No.049 sampai dengan No. 053 tahun 1987. PP itu kemudian disusul lagi dengan PP No. 51 tahun 1993 sebagai penyempurnaan Amdal sebelumnya dan diikuti oleh Kepmen LH No. 10-14 tahun 1994. Kepmen LH No. 10 mencabut Kepmen KLH no. 049 - 053 tahun 1987. No. 11 ketetapan tentang jenis usaha atau kegiatan yang wajib dilengkapi Amdal, sedangkan Kepmen LH no. 13 - 14 tahun 1994 menyempurnakan Kepmen KLH no. 51 - 53 tahun 1987. Selain itu, sudah diterbitkan UU No. 5 tahun 1992 tentang Benda Cagar Budaya.

Begitu banyak peraturan telah dikeluarkan, namun pelanggaran dan perusakan masih juga berlangsung. Kurangnya koordinasi antarinstansi yang berwenang merupakan masalah lain yang juga dapat membuka peluang terjadinya pelanggaran itu. Selain itu, minimnya pemahaman sebagian besar penduduk terhadap nilai sejarah yang terkandung dalam peninggalan arkeologi telah menambah kendala pada pelaksanaan peraturan. Masih diperlukan upaya-upaya lain selain menyusun dan memberlakukan peraturan-peraturan, terutama yang

\section{Volume XI \\ Nomor 02


menyangkut pemahaman penduduk terhadap pentingnya warisan budaya bagi jati diri masyarakat setempat. Untuk itu kawasan yang mengandung deposit benda bersejarah tersebut harus dapat dimunculkan sebagai sumber daya yang dapat memberikan manfaat secara berkelanjutan bagi penduduk.

Sumber daya alam di situs Trowulan dan sekitarnya cukup potensial mendukung kehidupan kota. Bahan alam dari gunung api yang ada di sisi selatan mempersubur tanah, dan sungai-sungai yang mengalir memungkinkan pembangunan irigasi untuk pertanian basah. Namun dalam pemanfaatan sumber alam yang keliru seperti penggunaan lempung dan kayu bakar secara besar-besaran dapat pula menimbulkan kerusakan lingkungan di situs ini. Dalam pemanfaatan sumber daya alam perlu diperhatikan empat lingkungan yang saling berkaitan erat, yakni: lingkungan perlindungan yang matang, lingkungan produksi yang bertumbuh, lingkungan serba guna serta lingkungan permukiman dan industri. Dalam konsep ini lingkungan produksi tidak dapat berdiri sendiri tanpa menghiraukan lingkungan perlindungan serta lingkungan permukiman dan industri, begitu pula sebaliknya dan demikian seterusnya (Haeruman, 1983:12).

Secara ekonomi beberapa bentuk peninggalan purbakala memang dinilai cukup tinggi. Bata bangunan kuna misalnya, dapat dimanfaatkan untuk bangunan rumah sekarang, pagar atau sebagai bahan dasar semen yang laku diperdagangkan. Bata itu diperoleh melalui penggalian tanah secara terusmenerus. Eksploitasi lingkungan seperti itulah yang menimbulkan bencana alam seperti banjir dan pendangkalan sungai yang pada gilirannya dapat mengganggu kehidupan manusia dan makhluk hidup lain. Untuk itulah situs Trowulan perlu mendapat perlindungan secara hukum.

Proses perusakan terhadap lingkungan berikut benda-benda bersejarah di situs Trowulan secara berlarut-larut disebabkan dua faktor yakni:

a. Di satu sisi, terdapat rendahnya penilaian penduduk terhadap tata lingkungan dan benda bersejarah yang terdapat pada situs, sehingga terjadi perusakan, dan

b. Di sisi lain, masyarakat lokal mungkin kurang dilibatkan secara aktif (partisipasi) dalam mengelola situs Trowulan yang secara nyata mengandung potensi ekonomi, budaya dan sosial bagi pengembangan wisata sejarah. Akibatnya pengawasan dari pihak aparat berwenang perlu dilaksanakan secara terus-menerus.

Pengawasan tersebut sebetulnya tidak perlu dilaksanakan secara terus-menerus apabila masyarakat dilibatkan secara aktif dalam pelestarian
Kawasan Lindung Trowulan. Selama ini tidak nampak adanya partisipasi yang aktif dari masyarakat di kawasan itu, sehingga tidak mengherankan terjadi kerusakan situs yang berkepanjangan dan lebih jauh rusaknya lingkungan fisik Trowulan. Masyarakat Trowulan juga harus disadarkan bahwa jika suatu saat sumber daya alam akan menipis maka harganya akan meningkat dan bukan tidak mungkin permintaan bata berangsurangsur akan menurun.

Dalam keadaan demikian teknologi dipaksa untuk menemukan substitusi bahan atau materi yang mulai menipis tersebut. Kecenderungan menguras sumber daya alam, baik yang hayati maupun nonhayati perlu dibatasi dengan upaya penghematan. Untuk kasus di Trowulan ini upaya penghematan yang bisa dilakukan mungkin dengan menerapkan prinsip mengganti (replacement). Misalnya, industri bata yang mungkin merusak tanah subur seperti sawah dapat diganti dengan industri batako yang menggunakan bahan dari bukit atau bahan yang gersang (Soerjani, 1997:91). Jika saja penduduk diajak partisipasi secara aktif setidaknya dapat diperoleh informasi sejauh apa kebutuhan ekonomis mereka dan bagaimana perilaku mereka terhadap Kawasan Lindung Trowulan.

Untuk mengatasi persoalan tersebut diperlukan strategi pemecahan masalah yang berorientasi pada partisipasi masyarakat. Dengan pertimbangan tersebut maka strategi pemecahan masalah yang dipilih untuk digunakan dalam penelitian adalah melalui metode Participatory Rural Appraisal dan Rapid Rural Appraisal.

Partisipasi aktif masyarakat juga berkaitan dengan sistem budayanya. Untuk mewujudkan partisipasi aktif pada masyarakat sekitar Kawasan Lindung ini, salah satu aspek penting yang diajukan adalah pengaruh sistem budaya. Bagaimanapun sistem budaya akan berpengaruh terhadap sikap dan perilaku masyarakat terhadap pelestarian situs. Dengan memperhatikan aspek-aspek itu diharapkan dapat dirumuskan solusi masalah pada Kawasan Lindung Trowulan agar tidak terjadi perusakan lingkungan berikut benda bersejarahnya.

\section{Perumusan Masalah}

1. Apakah terdapat perbedaan partisipasi masyarakat dalam pelestarian Kawasan Lindung Trowulan antara yang diberi perlakuan dengan metode Partisipatory Rural Appraisal dan Rapid Rural Appraisal?

2. Apakah terdapat perbedaan partisipasi masyarakat dalam pelestarian Kawasan Lindung Trowulan antara yang diberi perlakuan dengan metode Partisipatory Rural Appraisal dan Rapid Rural 
Appraisal, bagi masyarakat dengan pemahaman budaya yang tinggi?

3. Apakah terdapat perbedaan partisipasi masyarakat dalam pelestarian Kawasan Lindung Trowulan antara yang diberi perlakuan dengan metode Partisipatory Rural Appraisal dan Rapid Rural Appraisal, bagi masyarakat dengan pemahaman budaya yang rendah?

4. Apakah terdapat interaksi antara Strategi Pemecahan Masalah dan Pemahaman Budaya terhadap partisipasi masyarakat dalam pelestarian Kawasan Lindung Trowulan?

\section{A. DESKRIPSI TEORETIS}

\section{Partisipasi Masyarakat dalam Pelestarian Kawasan Lindung Situs Trowulan}

Istilah partisipasi cukup luas dipakai di kalangan masyarakat, terutama di lingkungan organisasi, perkumpulan atau kegiatan kelompok. Pengertian partisipasi berasal dari bahasa Latin berbentuk kata kerja "participare" yang bermakna peran serta atau menjadi terlibat. Keith Davis mengemukakan partisipasi adalah keterlibatan mental, fisik dan emosional orang dalam situasi kelompok untuk memberikan kontribusi kepada tujuan kelompok dan berbagi tanggung jawab dalam pencapaian tujuan.

Ada tiga unsur penting di dalam definisi tersebut yakni 1) Unsur peran serta, yaitu bahwa partisipasi sesungguhnya merupakan suatu keterlibatan mental dan perasaan daripada sekedar keterlibatan secara fisik, 2) Unsur kontribusi, yaitu kesediaan memberi sumbangan kepada usaha yang akan dilakukan guna mencapai tujuan kelompok. Ini berarti terdapat rasa senang, kesukarelaan untuk membantu kelompok, dan 3) Unsur tanggung jawab, yaitu bahwa partisipasi mendorong untuk menerima tanggung jawab dalam aktivitas kelompok (Davis, 1979:152).

Partisipasi masyarakat merupakan proses panjang di mana masyarakat turut serta mengambil bagian dalam pengambilan keputusan. Masyarakat yang dimaksud dalam uraian ini adalah masyarakat yang terkena dampak (affected people). Keikutsertaan publik akan membawa pengaruh positif. Mereka akan bisa memahami atau mengerti berbagai permasalahan yang muncul serta memahami keputusan akhir yang akan diambil. Pada hakikatnya pelibatan masyarakat merupakan bagian dari proses perencanaan yang dimaksudkan untuk mengakomodasi kebutuhan, aspirasi, dan kepedulian dari mereka.

Selanjutnya menurut Allport dalam Sastropoetro dinyatakan bahwa partisipasi adalah keterlibatan ego atau diri sendiri/personalitas lebih daripada sekadar keterlibatan secara fisik saja. Hal ini berarti bahwa jika seseorang berpartisipasi dalam kegiatan tertentu maka keterlibatannya bukan hanya secara fisik, tetapi lebih dalam lagi yaitu mencakup pikiran, perasaan dan kemauan (Sastropoetro, 1995:23). Untuk menumbuhkan kegiatan partisipasi diperlukan suatu keterampilan dan pengetahuan agar dapat mencapai berbagai tingkatannya, dan agar selalu dapat ditemukan titik-tolak untuk mengawalinya.

Dengan memperhatikan perbedaan tingkatan yang ada, maka pada dasarnya terdapat tiga tingkatan partisipasi. Pertama, tingkat saling mengerti. Tujuannya adalah untuk membantu para anggota kelompok agar memahami masing-masing fungsi dan sikap, sehingga dapat mengembangkan kerja sama yang lebih baik. Dengan demikian secara pribadi mereka akan menjadi lebih banyak terlibat, bersikap kreatif dan juga menjadi lebih bertanggung jawab. Kedua, tingkat penasihatan. Tahap ini dibangun atas dasar saling mengerti, oleh karena para anggota kelompok pada hakikatnya sudah cenderung siap untuk memberikan usul atau saran jika telah memahami masalah dan situasi yang dihadapkan kepada mereka. Ketiga, tingkat otoritas. Otoritas pada dasarnya memberikan kepada kelompok suatu wewenang untuk memantapkan keputusannya.

Lebih jauh Keith Davis berpendapat bahwa partisipasi adalah ikut sertanya mental dan emosi seseorang dalam situasi kelompok yang akan memberikan sumbangan tanggung jawab atas pencapaian tujuan. Dengan kata lain partisipasi adalah ikut sertanya seseorang secara aktif dan bertanggung jawab dalam suatu proses pencapaian tujuan kelompok atau organisasi di mana seseorang berada.

Pengertian tersebut di atas sejalan dengan pendapat Ramos yang menyatakan partisipasi merupakan keterlibatan mental, fisik dan emosional seseorang dalam situasi kelompok dalam memberikan kontribusinya kepada tujuan kelompok dan berbagi tanggung jawab dalam mencapai tujuan. Teori ini mengandung tiga gagasan yaitu: keterlibatan, kontribusi dan tanggung jawab (Ramos, 1986:97-99).

Partisipasi adalah peran serta seseorang atau sekelompok orang dalam suatu kegiatan. Partisipasi adalah tindakan ambil bagian terhadap suatu kegiatan untuk kepentingan bersama. Partisipasi berkenaan dengan kesiapan, kesepakatan, aktivitas dan tanggung jawab secara pasti (Yeung, 1986:9-14).

John M. Chohan dan Norman Uphoff mempunyai pendapat yang lebih-kurang serupa berkenaan dengan partisipasi, khususnya pada masyarakat desa. Menurut Chohan dan Uphoff, partisipasi merupakan keikutsertaan setiap orang di dalam setiap usaha perencanaan, pelaksanaan, dan pengawasan dalam menguasai dan memelihara 
lingkungan (Chohan and Norman $\mathrm{T}$ Uphoff, 1977:17).

Partisipasi dapat dimulai dari tahap menentukan mana yang akan dituju dan apa yang akan dihasilkan, atau biasanya disebut dengan tahap rumusan kebijakan dan rencana. Selanjutnya diikuti dengan partisipasi pada tahap menentukan cara untuk mencapai tujuan dan mempertaruhkan sumber daya agar tujuan dapat dicapai. Akhirnya partisipasi sampai pada tahap mencapai kesamaan pandangan tentang bagaimana memantau dan menilai hasilnya. Dengan demikian secara umum dapat dimengerti bahwa partisipasi dapat dilakukan mulai dari tahap perumusan kebijakan dan penyusunan rencana, tahap implementasi sampai pada tahap pemantauan dan evaluasi. Jelasnya partisipasi dapat dilakukan pada setiap tahap dalam daur taat penyelenggaraan kehidupan (Sumarto, 2003:187).

Menurut FAO, sebagaimana dikutip Mikkelsen arti partisipasi antara lain: (1) pemekaan (membuat peka) pihak masyarakat untuk meningkatkan kemauan menerima dan kemampuan untuk menanggapi projek-projek pembangunan, (2) keterlibatan masyarakat dalam pembangunan diri, kehidupan dan lingkungan mereka, (3) suatu proses yang aktif, yang mengandung arti bahwa orang atau kelompok yang terkait mengambil inisiatif dan menggunakan kebebasannya untuk melakukan hal-hal itu (Mikkelsen, 2001:64). Sementara itu, Sutrisno mendefinisikan partisipasi sebagai kerja sama antara rakyat dan pemerintah dalam merencanakan, melaksanakan dan mengembangkan hasil pembangunan (Sutrisno, 1995:207).

Menurut De Young partisipasi dikaitkan dengan psikologi lingkungan. Partisipasi biasanya dilakukan untuk mempertinggi keterlibatan masyarakat di dalam pola lingkungan. Hal ini menyangkut tidak hanya peningkatan pemahaman penduduk akan masalahmasalah tentang isu lingkungan, tetapi juga menyangkut peran serta sedini mungkin dan sungguh-sungguh dalam mencapai tujuan, perencanaan dan pengelola lingkungan tersebut (Young, dalam http://home.mira.net/gaffcam/ phil/russel/htm). Sejalan dengan pendapat De Young, Isbandi (2001:208) pun menyatakan bahwa dalam pemikiran mengenai partisipasi masyarakat, keterlibatan mereka tidak hanya dilihat pada tahap perencanaan dan pelaksanaan saja tetapi meluas hingga tahap assessment dan evaluasi

Tujuan partisipasi adalah menghasilkan pemberdayaan, yakni setiap orang berhak menyatakan pendapat dalam pengambilan keputusan yang menyangkut kehidupannya. Untuk mencapai tujuan itu, ada beberapa elemen partisipasi masyarakat yang harus dipenuhi. Pertama, adanya komunikasi dua arah yang terus-menerus. Kedua, informasi yang berkenaan dengan projek, program atau kebijaksanaan disampaikan dengan bermacammacam teknik yang tidak hanya pasif dan formal tetapi juga aktif dan informal (Hadi, 2002:93).

Partisipasi bukanlah proses alami, tetapi melalui proses pembelajaran. Ada beberapa bentuk partisipasi, antara lain: (1) inisiatif/spontan yaitu masyarakat secara spontan melakukan aksi bersama. Ini adalah bentuk partisipasi paling alami. Bentuk partisipasi spontan ini sering terjadi karena termotivasi oleh keadaan yang tiba-tiba, seperti bencana atau krisis, (2) fasilitasi, yaitu suatu partisipasi masyarakat disengaja, yang dirancang dan didorong sebagai proses belajar dan berbuat oleh masyarakat untuk membantu menyelesaikan masalah bersama, (3) induksi, yaitu masyarakat dibujuk berpartisipasi melalui propaganda atau mempengaruhi melalui emosi dan patriotisme, (4) koptasi, yaitu masyarakat dimotivasi untuk berpartisipasi untuk keuntungan-keuntungan materi dan pribadi yang telah disediakan untuk mereka, (5) dipaksa, yaitu masyarakat berpartisipasi di bawah tekanan atau sanksi-sanksi yang dapat diberikan penguasa. Bentuk partisipasi yang diharapkan adalah inisiatif/spontanitas, namun sering tidak terjadi sehingga diperlukan upaya dari luar. Memilih proses induksi, koptasi, dan dipaksa hasilnya akan relatif bersifat sementara. Partisipasi tidak akan banyak bermanfaat bagi masyarakat. Proses yang paling baik adalah fasilitasi. Dengan fasilitasi, masyarakat diposisikan sebagai dirinya, sehingga dia termotivasi untuk berpartisipasi dan berbuat sebaiknya untuk keuntungan dirinya (Daniel,dkk., 2006:60).

Istilah pelestarian dalam bahasa Inggris diterjemahkan dengan kosa kata conservation. Dalam perbendaharaan kata Indonesia, untuk padanan istilah pelestarian kadang digunakan kata bermakna sama yakni konservasi. Istilah konservasi mulai bergulir sejak tahun 1907 di Amerika Serikat setelah terjadinya penyusutan sumber daya alam secara cepat. Sebelumnya istilah ini hanya digunakan dalam kepekaan terhadap kelangsungan suatu kelembagaan sosial, daya prerogatif sosial, juga peruntukan untuk makna "status quo". Pengertian konservasi dalam Burra Charter dinyatakan sebagai berikut: konservasi adalah semua proses kegiatan sedemikian rupa terhadap place untuk melestarikan nilai penting budayanya. Dimaksudkan dengan place yaitu situs, areal, bangunan atau hasil karya lainnya, kelompok bangunan atau hasil karya lainnya termasuk kandungan isi serta lingkungannya (Tjandrasasmita, 1995:3). Beberapa cara penanganan pelestarian yang dikutip dari Piagam Burra dan menunjukkan tingkatan pemeliharaan kawasan yang dilestarikan 
adalah: (1) pengawetan, (2) pemugaran, (3) penguatan, (4) pembangunan ulang atau rekonstruksi, (5) pemakaian baru (adaptive reuse), (6) pembuatan kembaran, dan (7) demolisi.

Menurut Edi Sedyawati, pelestarian kebudayaan berarti membuat kebudayaan yang bersangkutan tetap ada. Pelestarian budaya dalam arti yang dinamis tidak berarti hanya mempertahankan bentuk-bentuk lama yang sudah pernah ada saja, melainkan menjadikan kebudayaan bersangkutan tetap ada dan tetap hidup dengan segala peluang perubahannya. Upaya pelestarian dapat dikelompokkan ke dalam tiga unsur, yakni : perlindungan, pengembangan, dan pemanfaatan. Usaha-usaha perlindungan yang termasuk ke dalam upaya pelestarian meliputi usaha untuk merawat suatu khasanah budaya yang bersifat kebendaan maupun yang bukan benda yang dapat diraba (intangible) seperti sastra, musik, tari dan lainlain. Pencegahan dari kepunahan termasuk ke dalam usaha perlindungan. Usaha-usaha pengembangan meliputi penyediaan peluang, atau sering disebut sebagai situasi yang kondusif untuk terjadinya penciptaan atau pembaharuan dalam berbagai unsur kebudayaan. Usaha pemanfaatan khasanah budaya antara lain untuk pengembangan industri budaya baik untuk keperluan perdagangan dan pariwisata maupun untuk kepentingan pendidikan masyarakat (Sedyawati, 1999:59).

Pelestarian mencakup tiga macam aspek, yakni: perlindungan, pemeliharaan, dan pemanfaatan (Mundardjito, 2005:1). Upaya pelestarian budaya, khususnya Kawasan Lindung yang mengandung benda-benda bernilai sejarah tidak hanya menyangkut masalah teknis penerapan teknologi konservasi ataupun aspek peraturan (legal) dan kebijakan. Masalah pelestarian juga telah mencapai aspek sosial yang di dalamnya terdapat unsur norma, tradisi, dan perilaku penduduk yang turut dibentuk oleh situasi ekonomi dan lingkungan. Pelestarian adalah juga upaya memberi makna baru dan dalam masyarakat yang pluralistik, pemberian makna tersebut dapat beragam. Karena itu pelestarian budaya harus dibicarakan bersama, dinegosiasikan, dan perlu disepakati bersama pula melalui suatu dialog yang terbuka dan seimbang (Tanudirjo, 2003:112).

Dalam pada itu Stanley A. Cain mengidentifikasikan pelaksanaan dasar pelestarian lingkungan fisik yang dijabarkannya dalam tiga aspek pula, yakni (1) aspek Pemeliharaan (preservasi), mencakup usaha-usaha pemeliharaan, pengawetan dan perlindungan berbagai sumber daya dari tindakan perusakan dan tindaklan negatif lainnya, (2) aspek Perbaikan (restorasi), mencakup berbagai usaha perbaikan, pemulihan dan peningkatan nilai asli dan produktivitas sumber daya yang rusak karena kekeliruan yang terjadi di dalam pemanfataan sumber daya tersebut, dan (3) aspek Pemanfaatan yang berkelanjutan, mencakup pengembangan teknik pengelolaan, penggantian sumber daya langka, pengurangan limbah, penggunaan kembali dan pemanfaatan suatu sumber daya seoptimal mungkin (Owen, 1985:11 - 14).

Pelestarian dapat pula didefinisikan sebagai pendayagunaan biosfir oleh manusia sehingga dihasilkan keuntungan yang berkesinambungan dan sangat besar bagi generasi sekarang sambil memelihara potensinya untuk memenuhi kebutuhan dan aspirasi generasi mendatang. Pada prinsipnya, pelestarian meliputi aspek perlindungan, pemeliharaan, pendayagunaan yang berkesinambungan, restorasi, dan peningkatan lingkungan alamiah yang positif dan menyeluruh (McNeely, 1988:227).

Berdasarkan pada beberapa pengertian tentang partisipasi bila dihubungkan dengan partisipasi masyarakat dalam pelestarian kawasan lindung Trowulan, maka partisipasi adalah wujud keterlibatan masyarakat yang didasarkan pada aspek personalitas, kerja sama, dan pengambilan peran dalam pemeliharaan, perlindungan, dan pemanfaatan kawasan lindung Trowulan.

\section{Strategi Pemecahan Permasalahan}

Metode lain yang dapat digunakan dalam menelaah kegiatan pembangunan bagi masyarakat umum agar ikut berperan serta dalam mempertimbangkan kelayakannya dapat ditelusuri melalui cara kontekstualisasi progresif dan analisis kejadian. Kontekstualisasi progresif (progressive contextualization) adalah pendapat yang dikemukakan oleh seorang antropolog A.P. Vayda yang pada dasarnya menganjurkan agar dalam kekompleksan masalah lingkungan hendaknya kita tidak melihat sesuatu hanya sesaat saja secara situasional (Soerjani, 2005). Suatu gejala, peristiwa, keadaan satu masalah perlu dilihat dalam analisis sebab-akibat serta dimensi ruang dan waktu secara berbeda-beda. Vayda mengakui bahwa istilah yang dianjurkannya itu merupakan "non technical language”. Ada beberapa hal yang menjadi dasar pendekatan kontekstual progresif ini yang perlu diperhatikan:

(1) Unit penelitian tidak dapat dibatasi hanya dengan unit ekosistem atau wilayah administrasi saja, karena masalah perilaku manusia dapat melampaui batas-batas itu (across the boundaries).

(2) Perlunya disadari asumsi yang kurang tepat tentang stabilitas suatu unit atau sistem, karena

\section{\begin{tabular}{l|l} 
Volume XI & Nomor 02 \\
\hline
\end{tabular}}


dalam banyak hal, unit atau sistem itu bersifat dinamik atau bahkan sangat dinamik.

(3) Perlunya memperhatikan ruang gerak waktu, upaya dan sumber daya yang mungkin terbatas.

(4) Perlunya pendekatan lintas disiplin (crossdicipline) dalam pengelolaan sumber daya (natural system) oleh manusia (anthropocentric or social system).

(5) Makna praktis dari hasil penelitian dan hubungannya dengan pengambil kebijakan (policymakers).

Sebuah industri bata, logam atau batu andesit yang direncanakan untuk didirikan di desa A, misalnya perlu ditelusuri secara progresif tidak hanya hubungan atau dampaknya masyarakat di desa A, tetapi juga desa lain $\mathrm{B}$ atau $\mathrm{C}$ yang mungkin akan tertarik atau diperlukan tenaganya untuk pendirian industri sedangkan yang diperlukan sebagai tenaga kerja industri mungkin dari desa D.

Analisis kejadian atau incidence analysis adalah pertanyaan tentang implikasi kesejahteraan dari program pembangunan. Sejak awal tahun 1970 telah dirasakan bahwa pertumbuhan ekonomi mulai tidak memberikan makna sebagai pengangkatan derajat kesejahteraan mereka yang miskin. Pada saat itu perencana pembangunan mulai memikirkan bagaimana pembangunan dapat ditujukan bagi (1) pencukupan kebutuhan dasar; (2) penciptaan kesempatan berusaha/bekerja; (3) peningkatan produktivitas mereka yang miskin; (4) mengurangi kesenjangan pendapatan, dan ketidakadilan.

Kegiatan industri pembuatan bata di Trowulan, sesuai dengan peraturan Pemerintah Republik Indonesia Nomor 27 tahun 1999 tentang Analisis Mengenai Dampak Lingkungan Hidup pasal 3, termasuk kegiatan yang kemungkinan dapat menimbulkan dampak besar dan penting terhadap lingkungan hidup. Pada pasal tersebut secara nyata disebutkan bahwa kegiatan semacam itu antara lain meliputi: eksploitasi sumber daya alam baik yang terbaharui maupun yang tak terbaharui, proses dan kegiatan yang hasilnya dapat mempengaruhi lingkungan alam, lingkungan buatan, serta lingkungan sosial dan budaya.

Upaya untuk mengurangi dampak dan risiko bagi masyarakat harus diperhitungkan sebagai biaya sosial pembangunan. Karena itu mulai perlu dipikirkan perlunya memilih-milah peranan stakeholder pembangunan yang terdiri atas (1) Eksekutif, pemerintah yang mengatur kebijakan, (2) Swasta yang bergerak di bidang bisnis, baik industri maupun pelayanan jasa/barang, (3) Lembaga pendidikan yang menghasilkan tenaga kerja pembangunan, (4) Masyarakat luas, baik perorangan maupun organisasi masyarakat, (5) Media Masa, sumber informasi. Sementara itu Stakeholder terdiri atas (a) Shareholders, atau stakeholder aktif yakni para pemrakarsa, pemodal, pelaksana yang langsung terlibat dan (b) Affected, atau stakeholder pasif yakni penanggung atau penerima makna, dampak dan risiko pembangunan.

Jadi setiap program pembangunan tidak cukup memperhitungkan keuntungan yang diperoleh shareholder, tetapi juga bagaimana mereka yang tidak langsung terlibat akan menerima akibat, dampak atau risiko. Contohnya adalah: Pendirian industri air minum, tidak hanya keuntungan pemilik pabrik yang harus diperhitungkan, tetapi para penjual air bersih keliling perlu dicari cara pengalihan profesinya, mungkin sebagai karyawan industri air minum atau agen-agennya (Soerjani, 2005). Kasus yang serupa berkaitan dengan perajin industri bata di Trowulan. Jika larangan eksploatasi bata hendak diberlakukan, nasib para perajin perlu disalurkan ke arah yang tetap memberi peluang pekerjaan bagi mereka, apakah sebagai pemandu wisata, penjaja cenderamata, pedagang makanan-minuman dan lain sebagainya. Dengan demikian berbagai program pembangunan perlu dianalisis secara cermat kejadian apa yang akan timbul, baik bagi pelaksana maupun penderita.

Strategi pemecahan masalah merupakan sebuah pola atau rencana yang mengintegrasikan sasaran utama suatu organisasi, kebijakan-kebijakan dan rangkaian tindakan ke dalam suatu kesatuan yang menyeluruh. Lebih lanjut Henry Mintzberg dan James Brian Quinn menambahkan bahwa suatu strategi yang dirumuskan dengan baik dapat membantu dalam menyusun dan mengalokasikan sumber daya organisasi ke dalam suatu postur yang spesifik dan aktif berdasarkan kemampuan dan kelemahan internalnya serta perkiraan atas perubahan lingkungan (Mitzberg, Henry \& Quinn James Brian 1992:25).

Pemecahan masalah memerlukan pemahaman tentang proses, latar belakang serta faktor-faktor yang menyebabkan terjadinya kondisi munculnya masalah tersebut. Proses pemecahan masalah meliputi tiga tahap yakni (1) trend impact analysis, (2) cross impact analysis dan (3) scenarios. Tahap pertama melihat kecederungan gejala masalah yang terjadi. Tahap ke dua melihat keterkaitan masalah yang diidentifikasi tersebut dengan berbagai faktor dan fenomena yang dapat memberi gambaran tentang faktor penyebab serta kompleksitas masalah, sehingga identik dengan upaya mendiagnosis masalah. Tahap ke tiga merumuskan dan merekomendasikan langkah-langkah yang harus diambil untuk usaha pemecahan dan perbaikan (treatment) (Parillo, 1997:19-23). 
Sementara itu pentahapan dalam strategi pemecahan dikemukakan pula oleh Raab dan Selznick (1994:29-30). yang membaginya ke dalam tahap measurement, causation, dan meeting. Dimaksud dengan measurement adalah pengukuran untuk mengidentifikasi keberadaan masalah. Untuk melakukan identifikasi dibutuhkan instrumen dalam rangka menentukan apakah dalam kehidupan masyarakat tertentu pantas dinyatakan sebagai mengandung gejala sebuah masalah. Sementara itu tahap causation dan meeting secara jelas cukup paralel dengan langkah diagnosis dan treatment.

Berkaitan dengan strategi pemecahan masalah, Jim Ife dan Frank Tesoriero berpendapat bahwa dalam memecahkan masalah, khususnya masyarakat desa patut diperhitungkan pengetahuan masyarakat lokal. Tidak setiap masalah harus diselesaikan oleh pihak luar. Melibatkan konsultan dari pihak luar berarti menghilangkan nilai pengetahuan lokal, karena seolah-olah tidak ada partisipasi masyarakat dalam memecahkan masalah mereka sendiri. Hal itu hanya akan melemahkan dan bahkan menurunkan nilai kearifan dan keahlian masyarakat setempat (Ife, Jim dan Frank Tesoriero, 2008:249).

Pendapat senada dikemukakan pula oleh Ann Braun yang menyatakan bahwa dalam memecahkan masalah perdesaan, penting dipertimbangkan partisipasi penduduk dan kesetaraan antara pendapat ahli dan pengetahuan penduduk lokal (indigenous knowledge) sehingga pengembangan masyarakat dapat lebih terbuka lebar (Braun dalam http// www.idrc.ca/en/ev-85059-201-1-DO_TOPIC).

Dengan demikian dapat dinyatakan bahwa Strategi Pemecahan Masalah adalah cara-cara yang dipilih untuk menyelesaikan persoalan dalam lingkungan tertentu, yang meliputi sifat, lingkup, dan urutan kegiatan secara sistematis melalui metode yang cocok dan pengetahuan yang dimilikinya guna mencapai tujuan yang akan dicapai.

\subsection{Partisipatory Rural Appraisal (PRA): penilaian} perdesaan secara partisipatif.

Metode PRA dan RRA mulai dikenal pada akhir tahun 1970-an ketika semakin terasa pentingnya memperhatikan kemungkinan yang dapat menjadi kesalahan fundamental pada pembangunan yang telah dikonsepkan, direncanakan, dan bahkan dilaksanakan. Organisasi yang sangat sering menganut paradigma partisipatoris adalah organisasi Non-Pemerintah (NGO). Mereka telah terbiasa mengembangkan sejumlah teknik interaksi yang efektif dengan masyarakat. Sebutan lain untuk metode ini di antaranya adalah penilaian perdesaan yang partisipatoris (PRA) dan penilaian perdesaan yang cepat (RRA) (Chambers, 1992:33).
Nama lain yang setara dengan PRA adalah PLA (Participatory Learning and Action), namun apa pun namanya prinsipnya adalah melakukan pengkajian komunitas sosial secara partisipatif sebagai upaya untuk menemukenali berbagai kebutuhan, aspirasi dan keadaan di komunitas tersebut, dan sekaligus pula dapat membuat perencanaan kegiatan pengelolaan lingkungan hidup, khususnya lingkungan sosial. PLA/PRA adalah kegiatan penelitian tentang aspek-aspek kehidupan masyarakat atau komunitas sosial tertentu yang dilakukan oleh warga masyarakat bersangkutan dengan didampingi atau difasilitasi oleh petugas lembaga pengembang program. Bagi lembaga pengembang program, kegiatan ini sebagai proses penyadaran dalam memahami kehidupan sosial, cara pandang, dan nilai-nilai budaya warga komunitas yang bersangkutan, yang secara langsung mempunyai pengaruh terhadap program itu sendiri. Dengan melakukan kegiatan bersama, penerapan program akan mudah memperoleh dukungan dari warga komunitas bersangkutan dan keputusan untuk melaksanakan program sudah merupakan kesepakatan antara pihak-pihak yang terlibat dalam program tersebut sejak perencanaan, pelaksanaan, monitoring dan evaluasi (Purba, 2002: 81 - 83).

Menurut Mitchell dkk, PRA adalah sebuah metode untuk mengkaji sistem pengetahuan lokal. Orientasi dari strategi ini untuk memfasilitasi atau meningkatkan kesadaran masyarakat dan kemampuan mereka untuk menangkap isu atau persoalan. Perhatian khusus diberikan agar masyarakat lokal dapat melakukan analisis secara mandiri serta menyampaikan temuan-temuannya. Peran peneliti menjadi katalis, bukan sebagai ahli. Peningkatan kesadaran dan pengetahuan masyarakat lokal juga ditujukan untuk membantu memberdayakan masyarakat. Selanjutnya mengingat eratnya hubungan antara masyarakat perdesaan dengan alam, hendaknya diusahakan pembinaan kesadaran dan pengetahuan masyarakat desa untuk ikut serta dalam pengelolaan sumber-sumber daya alam dan lingkungan hidup agar dapat dijamin kelestarian dan pemanfaatan yang sebaik-baiknya dari sumber daya alam dan lingkungan hidup alami tersebut. Dengan demikian masyarakat di daerah perdesaan akan merupakan penjaga dan pencegah kerusakan terhadap sumber daya alam dan lingkungan hidup alami pada umumnya. Dalam hubungan dengan ini adat kebiasaan masyarakat desa yang mendukung kelestarian sumber daya alam dan lingkungan hidup perlu dibantu untuk dipertahankan dan dikembangkan (Haeruman, 1983:29).

Sejalan dengan pendapat tersebut, Chambers juga menyatakan bahwa PRA adalah metode untuk mendorong masyarakat perdesaan ikut serta

\section{Volume XI \\ Nomor 02


menganalisis dan meningkatkan pengetahuan mereka mengenai kondisi hidup mereka sendiri agar dapat membuat rencana dan tindakan. Metode PRA sering kali dipahami sebagai pendekatan atau teknik untuk melibatkan masyarakat dalam proses perencanaan, pelaksanaan, serta pemantauan dan evaluasi program pembangunan masyarakat (Chambers,1991:953 969).

Mengenai metode PRA, pendapat lain juga dikemukakan oleh Suharto. Metode PRA merupakan alat pengumpulan data yang sangat berkembang dewasa ini. PRA terfokus pada proses pertukaran informasi dan pembelajaran antara pengumpul data dan responden (Suharto, 2005:92).

Tujuan utama dari PRA adalah untuk menjaring rencana atau program pembangunan perdesaan yang memenuhi persyaratan, diterima oleh masyarakat setempat, secara ekonomi menguntungkan dan sebaiknya juga berdampak positif pada lingkungan sekitarnya. Metode PRA dapat membantu dalam menggerakkan sumber daya alam dan manusia untuk memahami masalah, mempertimbangkan program yang telah sukses, menganalisis kapasitas kelembagaan lokal, menilai kelembagaan modern yang telah diintrodusir dan membuat rencana atau program spesifik yang operasional secara sistematis. Metode PRA lebih menekankan kerja sama yang melibatkan orang luar dan orang dalam secara bersama-sama menilai tentang status dan potensi sumber daya perdesaan dan memikirkan kesempatan kerja (Daniel, dkk., 2006:34).

Dalam hal kegunaannya, metode PRA banyak dilakukan oleh masyarakat perdesaan untuk memecahkan berbagai masalah seperti masalah pertanian, gender, kesehatan, pariwisata, kerusakan lingkungan, sarana pengairan, pendidikan dan masih banyak lagi (Doyle and Marianne Krasny, dalam http://www.garden mosaic.cornell.u)

\subsection{Rapid Rural Appraisal (RRA): penilaian perdesaan secara cepat.}

Mengenai RRA, oleh Mitchell dkk didefinisikan sebagai aktivitas yang sistematis tetapi cukup terstruktur, yang dilakukan di lapangan oleh sebuah tim multidisiplin dan dirancang untuk secara cepat mendapat informasi atau hipotesis tentang kehidupan desa (Mitchell, 2001:302-306).

Pada awalnya RRA dirancang untuk memfasilitasi pengumpulan data tentang sistem perdesaan atau ekosistem secara cepat. Memahami desa secara cepat lewat metode RRA berawal dari dua hal yakni (1) ketidakpuasan terhadap projek, bias jender, personal, kondisi musim yang tidak menentu dan kombinasi dari berbagai bias itu, dan (2) kekecewaan terhadap proses survei dan hasilnya, juga untuk mencari metode pemahaman yang lebih efektif, misalnya karena fakta bahwa penduduk desa memiliki berbagai macam pengetahuan lokal (local knowledge) dan kearifan lokal (local wisdom), sebagai kekayaan yang bermakna bagi kehidupan mereka. Tujuannya agar peneliti lebih peka dengan budaya dan sistem nilai lokal (Kistanto, 2003:23-24).

Metode RRA merupakan cara yang cepat dan murah untuk mengumpulkan informasi mengenai pandangan dan masukan dari populasi sasaran dan stakeholders lainnya mengenai kondisi geografis dan sosial ekonomi. Metode ini meliputi wawancara informan kunci (key informant interview), diskusi kelompok (focus group discussion), wawancara kelompok masyarakat (community group interview), pengamatan langsung (direct observation), dan survei kecil (mini survey) (Suharto, 2005:91).

Sebagai metode baru, RRA dirancang terutama untuk tim yang berbeda disiplin ilmu, guna dipakai untuk mengumpulkan dan menganalisis informasi atau data dalam jangka waktu yang singkat. Dengan metode ini tim dapat menganalisis dan menarik kesimpulan lebih komprehensif. Melalui metode ini, jawaban atas suatu masalah dapat diperoleh dalam waktu singkat dan biaya murah secara ilmiah pun dapat dipertanggungjawabkan. Metode RRA lebih diarahkan pada pemahaman permasalahan suatu tempat atau desa secara menyeluruh. Dalam pelaksanaannya metode ini sekaligus juga melakukan konfirmasi data, data sekunder dan pendalaman melalui wawancara dengan pengambil kebijakan. Kemudian data ini dikonfirmasikan ke lapangan. Dari lapangan didiskusikan oleh tim yang terdiri dari berbagai disiplin ilmu atau keahlian. Selanjutnya dicocokkan antara data sekunder tersedia dengan kenyataan yang ada di lapangan (Daniel, dkk., 2006:27).

Dari uraian di atas dapat dipahami bahwa PRA merupakan metode pemecahan masalah perdesaan yang lebih menekankan pada usaha-usaha untuk meningkatkan kemampuan masyarakat lokal dalam melakukan penelitian secara mandiri, mencari alternatif penyelesaian masalah dan penerapannya. PRA memungkinkan orang-orang desa mengungkapkan dan menganalisis situasi mereka sendiri, dan secara optimal merencanakan tekad itu di desanya sendiri. Dalam pada itu, RRA merupakan metode pemecahan masalah perdesaan yang dirancang untuk memungkinkan pihak luar secara cepat dan efisien dapat mengumpulkan data dan informasi tentang persoalan ekosistem setempat melalui kombinasi beberapa cara. Jika ditempatkan dalam konteks perencanaan dan pelaksanaan program-program kemasyarakatan, kini telah terjadi 
pergeseran paradigmatik dari metode RRA ke PRA yang meliputi:

(1) RRA yang berupa pendekatan “dari atas ke bawah” (top down) ke PRA yang berupa pendekatan "dari bawah ke atas" (bottom up).

(2) RRA yang berupa kebijakan "standarisasi terpusat” (centrally standardized) ke PRA yang berupa kebijakan "penganekaragaman setempat" (locally diversified).

(3) RRA yang cenderung sudah menyiapkan "cetak biru” (blue print) ke PRA yang memberi peluang masyarakat lokal untuk mengikuti "proses belajar” (learning process).

(4) RRA yang pola risetnya dari "survei dengan kuesioner" (survey) ke "analisis \& pemahaman secara partisipatif” (participatory analysis \& appraisal).

(5) RRA yang pola pikirnya dari "orang luar" (outsider/ethic: kerangka mental, kategori \& pandangan orang luar) ke PRA yang "berbasis komunitas” (community based/emic): kerangka mental dari dalam, yang dimiliki masyarakat sendiri), dalam hal ini konsultan/tenaga ahli (expertise) hanya menjadi fasilitator, yang melimpahkan wewenang kepada masyarakat (handling over the stick) dari tertutup ke terbuka.

Untuk lebih jelasnya, perbandingan penggunaan metode RRA dan PRA adalah sebagai berikut:

\begin{tabular}{|c|c|}
\hline RRA & PRA \\
\hline $\begin{array}{l}\text { Periode } \\
\text { pengembangan: akhir } \\
\text { 70-an dan 80-an }\end{array}$ & $\begin{array}{l}\text { Periode } \\
\text { pengembangan: akhir } \\
\text { 80-an dan 90-an }\end{array}$ \\
\hline $\begin{array}{l}\text { Penemu utama: } \\
\text { universitas dan } \\
\text { lembaga penelitian }\end{array}$ & $\begin{array}{l}\text { Penemu utama: } \\
\text { Lembaga Swadaya } \\
\text { Masyarakat (LSM) }\end{array}$ \\
\hline $\begin{array}{l}\text { Pengguna utama: } \\
\text { lembaga donor, } \\
\text { universitas, dan } \\
\text { lembaga penelitian }\end{array}$ & $\begin{array}{l}\text { Pengguna utama: LSM } \\
\text { dan pemerintah lokal } \\
\text { yang bergerak di } \\
\text { lapang }\end{array}$ \\
\hline $\begin{array}{l}\text { Tujuan ideal: belajar } \\
\text { dari luar }\end{array}$ & $\begin{array}{l}\text { Tujuan ideal: kekuatan } \\
\text { masyarakat }\end{array}$ \\
\hline $\begin{array}{l}\text { Sumber yang sering } \\
\text { terlupakan: } \\
\text { pengetahuan } \\
\text { masyarakat setempat }\end{array}$ & $\begin{array}{l}\text { Sumber yang sering } \\
\text { terlupakan: } \\
\text { pemberdayaan } \\
\text { masyarakat }\end{array}$ \\
\hline $\begin{array}{l}\text { Fokus utama: } \\
\text { penggalian (extractive) }\end{array}$ & $\begin{array}{l}\text { Fokus utama: peran } \\
\text { serta (participatory) }\end{array}$ \\
\hline $\begin{array}{l}\text { Hasil akhir jangka } \\
\text { panjang: perencanaan, } \\
\text { projek dan publikasi }\end{array}$ & $\begin{array}{l}\text { Hasil akhir jangka } \\
\text { panjang: aksi } \\
\text { masyarakat yang } \\
\text { berlanjut termasuk }\end{array}$ \\
\hline
\end{tabular}

kelembagaan

digunakan bagi masyarakat sehingga mereka berpartisipsi dalam pelestarian kawasan lindung Trowulan adalah didasarkan pada metode Participatory Rural Appraisal (PRA) dan sebagai alternatif pembanding digunakan metode Rapid Rural Appraisal (RRA). Dengan demikian dapat dinyatakan bahwa metode PRA dan RRA pada dasarnya merupakan metode assessment terhadap perdesaan yang berupaya untuk mengoptimalisasi masyarakat setempat dan para ahli sehingga metode ini tidak saja bermanfaat bagi masyarakat setempat tetapi juga bagi para ahli (community worker).

\section{Pemahaman Budaya}

Pemahaman menurut Krathwolh, Bloom, dan Masia mencakup tiga jenis pengertian yaitu: pertama, menterjemahkan (translation), interprestasi (interpretation), dan ekstrapolasi (extrapolation) (Krathwohl,David R., Benjamin, Bloom, S., dan Masia, Bertram B, 1956:89). Translasi berarti menterjemahkan, di mana seseorang dapat menciptakan suatu proses komunikasi dalam bahasa yang lain atau dalam bentuk proses komunikasi yang lain.

Kedua, interpretasi yang berarti menafsirkan yaitu berkenaan dengan komunikasi yang lain sebagai suatu konfigurasi gagasan dengan penilaian yang mungkin memerlukan penyusunan kembali suatu konfigurasi baru dalam pemikiran seseorang. Ketiga, ekstrapolasi yang merujuk kepada pengertian, kemampuan untuk melakukan estimasi atau prediksi yang didasarkan pada kemampuan membaca perkembangan, kecenderungan, serta akibat atau kondisi yang dideskripsikan dalam proses komunikasi.

Harsja W. Bachtiar menyatakan bahwa, pengertian Sistem Budaya tidak dapat dilepaskan kaitannya dengan konsep sistem kebudayaan. Sistem kebudayaan adalah seperangkat pengetahuan yang meliputi pandangan hidup, keyakinan, nilai, norma aturan hukum yang menjadi milik suatu masyarakat melalui proses belajar, yang kemudian diacu untuk menata, menilai, dan menginterpretasi sejumlah benda dan peristiwa dalam beragam aspek kehidupan dalam lingkungan masyarakat yang bersangkutan (Bachtiar, 1984:18).

Sistem Kebudayaan memuat sejumlah konsep penting yaitu pengetahuan, nilai budaya, aturan, norma, hukum dan keyakinan. Menurut Koentjaraningrat nilai kebudayaan merupakan konsep-konsep mengenai apa yang hidup di alam pikiran sebagian besar dari warga suatu masyarakat mengenai apa yang mereka anggap bernilai, berharga,

\section{Volume XI \\ Nomor 02


dan penting dalam hidup sehingga dapat berfungsi sebagai pedoman yang memberi arah dan orientasi kepada kehidupan warga masyarakat (Koentjaraningrat, 2002:25-31).

Dalam kehidupan manusia sehari-hari, senantiasa terjadi interaksi timbal balik sistem sosial yang dipengaruhi latar belakang budaya dan sistem biofisik atau ekosistem. Menurut Terry A. Rambo, faktor-faktor sistem biofisik atau ekosistem di sekitar manusia sangat beragam bergantung pada dimana manusia tinggal, termasuk di dalamnya iklim, udara, air, tanah, tanaman, dan hewan. Jadi, kehidupan manusia sehari-hari tidak pernah lepas dari lingkungannya. Aspek latar belakang sosial-ekonomibudaya manusia dapat mempengaruhi perilaku manusia dalam memperlakukan alam lingkungan sekitarnya. Jika ada perubahan pada sistem sosial masyarakat secara otomatis akan berakibat pula pada sistem biofisiknya (Rambo, 1983:9).

Menurut Julian Steward (1982:71) dengan menggunakan kebudayaannya manusia melakukan adaptasi. Dalam Antropologi, studi semacam ini dinamakan sebagai ekologi manusia (human ecology) yang memusatkan perhatiannya kepada bagaimana manusia mengadaptasi dirinya dengan lingkungannya dan bagaimana kegiatan-kegiatan manusia telah mengubah dan membentuk ekosistem yang baru. Hubungan antara kebudayaan dengan alam sekitarnya dengan demikian dapat dijelaskan melalui aspekaspek tertentu dalam suatu kebudayaan.

Melalatoa berpendapat bahwa sistem budaya tersebar dalam unsur ilmu pengetahuan, sosial, seni dan religi (Melalatoa, 1997: 6). Max Weber seorang Sosiolog, berpandangan bahwa nilai budaya dapat berupa estetis, politik, religius dan moral (Veeger, 1986:137). Alisjahbana seorang budayawan berpendapat bahwa sistem nilai budaya terbagi ke dalam enam nilai, yakni nilai teori, nilai ekonomi, nilai agama, nilai seni, nilai kuasa dan nilai solidaritas (Alisjahbana, 1985:145). Malinowski, Sutherland dan Woodward, serta Ford (dalam A.L. Kroeber dan Clyde Kluckhohn, 1952) secara bersamaan menyimpulkan bahwa kebudayaan adalah segala sesuatu yang dapat dikomunikasikan dari satu generasi ke generasi berikutnya. Kebudayaan pada dasarnya adalah warisan sosial masyarakat bersangkutan yang meliputi ilmu pengetahuan, agama, kesenian, moral, hukum, teknik pembuatan dan penggunaan alat, cara berkomunikasi, kebiasaankebiasaan, dan juga proses belajar dalam memecahkan masalah (Kroeber, A.L. dan Kluckhohn, Clyde., 1952:47- 55).

Pada hakikatnya kebudayaan itu berkembang sebagai perwujudan tanggapan aktif manusia terhadap lingkungannya dalam arti luas. Dengan segala kemampuan yang dimiliki, manusia berusaha melihat, memahami, memilah-milah gejala untuk kemudian merencanakan tindakan dan menentukan sikap serta perbuatan yang menghasilkan karya.

Pada mulanya manusia menanggapi lingkungan dengan cara trial and error dan karena itu cepat lambatnya perkembangan suatu kebudayaan tergantung daripada sedikit banyaknya umpan balik yang dapat ditangkap oleh akal manusia dalam mengelola lingkungan (Soerjani, Mohamad, Ahmad, Rofiq dan Munir, Rozy., 1987:231).

Dengan demikian dapat disimpulkan bahwa Pemahaman budaya adalah kemampuan menterjemahkan, menafsirkan, dan mengektrapolasi seperangkat unsur kebudayaan (ilmu pengetahuan, sosial, seni, religi dan ekonomi) yang dimiliki manusia dan digunakan secara selektif dalam menghadapi lingkungannya.

\section{Kerangka Berpikir}

1. Perbedaan partisipasi masyarakat dalam pelestarian Kawasan Lindung Trowulan antara masyarakat yang dilibatkan dengan metode Partisipatory Rural Appraisal (PRA) dan Rapid Rural Appraisal (RRA)

Partisipasi masyarakat dalam pelestarian Kawasan Lindung pada dasarnya adalah keterlibatan anggota masyarakat secara aktif sejak tahap perencanaan, pelaksanaan, hingga evaluasi dalam kegiatan pelestarian kawasan lindung. Pelibatan masyarakat merupakan bagian dari proses perencanaan yang dimaksudkan untuk mengakomodasi kebutuhan, aspirasi dan kepedulian mereka. Dalam konteks ini metode PRA sejalan dengan beberapa konsepsi dasar tentang pembangunan berkelanjutan (pemberdayaan masyarakat lokal, persamaan, dan keadilan sosial).

Sedangkan metode RRA oleh sebagian peneliti masih diangap sebagai pengumpulan informasi yang prosesnya masih sepihak. Pengalaman yang diperoleh dengan RRA (awal 1980-an) menunjukkan RRA mudah terkena kritik karena predikat yang disandangnya yakni 'rapid' atau cepat. Dengan demikian dapat diduga bahwa pelestarian Kawasan Lindung Trowulan berdasarkan partisipasi masyarakat dengan metode PRA akan lebih baik daripada menggunakan metode RRA.

Dengan demikian dapat diduga bahwa strategi pemecahan masalah dengan metode PRA akan memberikan hasil lebih baik jika dibandingkan dengan metode RRA terhadap partisipasi masyarakat dalam melestarikan kawasan lindung Trowulan. 
2. Perbedaan partisipasi masyarakat dalam pelestarian kawasan lindung Trowulan antara yang dilibatkan dengan metode Participatory Rural Appraisal dan metode Rapid Rural Appraisal, bagi masyarakat yang mempunyai pemahaman budaya tinggi.

Bagi masyarakat yang memiliki pemahaman budaya tinggi cenderung memiliki kepedulian yang lebih besar terhadap kawasan lindung. Melalui metode PRA masyarakat menjadi lebih termotivasi karena dilibatkan secara aktif pada seluruh proses kegiatan pembangunan perdesaan tanpa melibatkan pihak luar.

Dengan demikian dapat diperkirakan partisipasi masyarakat dalam pelestarian kawasan lindung bagi masyarakat yang memiliki pemahaman budaya tinggi melalui metode PRA akan lebih baik dibandingkan dengan yang menggunakan metode RRA.

3. Perbedaan partisipasi masyarakat dalam pelestarian kawasan lindung Trowulan antara yang dilibatkan dengan metode Participatory Rural Appraisal dan metode Rapid Rural Appraisal, bagi masyarakat yang mempunyai pemahaman budaya rendah.

Bagi masyarakat yang memiliki pemahaman budaya rendah cenderung sulit untuk dilibatkan dalam memecahkan masalah pelestarian kawasan lindung. Mereka cenderung baru berpartisipasi apabila menghadapi pengawasan aparat dengan berbagai sanksi hukumnya. Namun apabila aparat mulai lengah dalam pengawasan, mereka cenderung mengulangi perbuatan lagi berupa perusakan lingkungan.

Dengan demikian dapat diduga bahwa partisipasi masyarakat dalam pelestarian kawasan lindung bagi masyarakat yang memiliki pemahaman budaya rendah melalui metode RRA akan lebih baik jika dibandingkan dengan metode PRA.

4. Interaksi antara Strategi Pemecahan Masalah dan Pemahaman Budaya terhadap partisipasi masyarakat dalam pelestarian kawasan lindung Trowulan

Untuk melestarikan kawasan lindung Trowulan melalui partisipasi masyarakat, bagi masyarakat yang memiliki pemahaman budaya tinggi lebih baik menggunakan metode PRA. Sementara itu bagi masyarakat yang memiliki pemahaman budaya rendah, maka metode RRA akan lebih tepat untuk digunakan.

Dengan demikian dapat diduga bahwa terdapat interaksi antara strategi pemecahan masalah dan pemahaman budaya terhadap partisipasi masyarakat dalam melestarikan kawasan lindung Trowulan.

\section{Hipotesis Penelitian}

Berdasarkan kajian teoretis dan kerangka

berpikir yang telah diuraikan di atas, maka diajukan

hipotesis penelitian sebagai berikut:

1. Secara keseluruhan, partisipasi masyarakat yang menggunakan metode PRA lebih baik daripada yang menggunakan metode RRA.

2. Bagi masyarakat yang memiliki pemahaman budaya tinggi, partisipasi masyarakat melalui metode PRA lebih baik daripada yang menggunakan metode RRA.

3. Bagi masyarakat yang memiliki pemahaman budaya rendah, partisipasi melalui metode RRA lebih baik daripada yang menggunakan metode PRA.

4. Terdapat interaksi antara strategi pemecahan masalah dan pemahaman budaya terhadap partisipasi masyarakat dalam pelestarian kawasan lindung Trowulan.

\section{B. METODOLOGI PENELITIAN}

\section{Tujuan Penelitian}

Berdasarkan perumusan masalah yang telah dikemukakan maka secara khusus tujuan penelitian ini adalah untuk:

1. Mengetahui perbedaan partisipasi masyarakat dalam pelestarian Kawasan Lindung Trowulan antara yang dilibatkan dengan metode Participatory Rural Appraisal dan metode Rapid Rural Appraisal.

2. Mengetahui perbedaan partisipasi masyarakat dalam pelestarian Kawasan Lindung Trowulan antara yang dilibatkan dengan metode Participatory Rural Appraisal dan metode Rapid Rural Appraisal, bagi masyarakat yang mempunyai pemahaman budaya tinggi.

3. Mengetahui perbedaan partisipasi masyarakat dalam pelestarian Kawasan Lindung Trowulan antara yang dilibatkan dengan metode Participatory Rural Appraisal dan metode Rapid Rural Appraisal, bagi masyarakat yang mempunyai pemahaman budaya rendah.

4. Mengetahui interaksi antara Strategi Pemecahan Masalah dan Pemahaman Budaya terhadap partisipasi masyarakat dalam pelestarian Kawasan Lindung Trowulan.

Penelitian ini dilakukan tahun 2005 terhadap masyarakat di Desa Sentonorejo dan Desa Bejijong, Kecamatan Trowulan, Kabupaten Mojokerto, Provinsi Jawa Timur. Kecamatan Trowulan dengan luasan wilayahnya 46,336 $\mathrm{km}^{2}$

\section{\begin{tabular}{|l|l|l|l|}
\hline Volume XI & Nomor 02 & Maret 2010 & ISSN 1411-1829 \\
\hline
\end{tabular}}


dan jumlah penduduk 57.227 jiwa memiliki kepadatan 1235 jiwa/ $\mathrm{km}^{2}$.

\section{Metode Penelitian}

Penelitian ini menggunakan desain eksperimen faktorial $2 \times 2$, yakni masyarakat di dua desa ke dalam dua kelompok yang berbeda perlakuannya (perlakuan metode PRA dan metode RRA). Masing-masing kelompok terdiri dari 40 orang sebagai sampel. Seluruh sampel akan dilakukan pengukuran variabel atribut (pemahaman budaya), sehingga masing-masing kelompok tersebut akan terdiri dari subkelompok orang yang mempunyai pemahaman budaya tinggi dan pemahaman budaya rendah.

Digunakannya metode penelitian eksperimen faktorial ini karena selain dapat melihat pengaruh salah faktor terhadap variabel $Y$, juga metode ini dapat memberikan ada atau tidaknya interaksi antarvariabel bebas $X$ (Faktor A dan Faktor B) terhadap variabel $Y$ (Partisipasi masyarakat dalam pelestarian Kawasan Lindung). Desain eksperimen tersebut sebagai berikut:

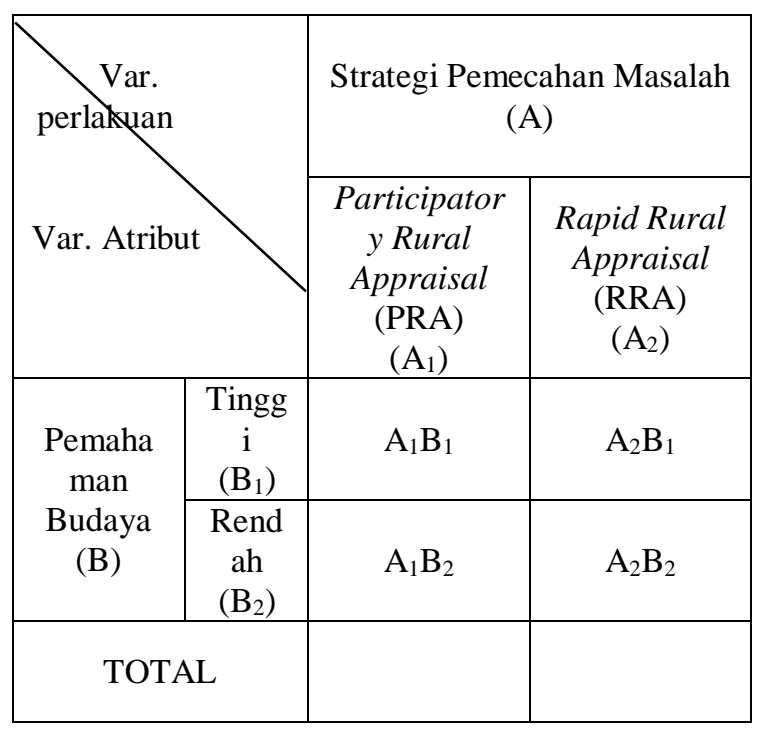

Keterangan :

\section{Gambar 1. Desain Eksperimen}

Variabel Terikat $(\mathrm{Y}) \quad=$ Partisipasi masyarakat dalam pelestarian

Kawasan Lindung Trowulan

Variabel Perlakuan $\left(\mathrm{X}_{1}\right)=$ Strategi Pemecahan Masalah (2 kategori)

Variabel Atribut $\left(\mathrm{X}_{2}\right) \quad=$ Pemahaman Budaya $(2$ kategori)
Untuk pengambilan sampel digunakan teknik random sampling. Populasi sebagai unit analisis adalah masyarakat yang tinggal di sekitar Cagar Budaya Trowulan, Kecamatan Trowulan, Kabupaten Mojokerto, Provinsi Jawa Timur. Sampel 60 orang penduduk dewasa (telah berkeluarga). Cluster sampling dilakukan pada 5 (lima) desa, yakni Desa Trowulan, Desa Sentonorejo, Desa Temon, Desa Jatipasar, dan Desa Bejijong. Melalui cluster sampling terpilih dua Desa yaitu Desa Sentonorejo dan Desa Bejijong. Di Desa Sentonorejo dilakukan random sampling sebanyak 30 orang yang mendapat perlakuan PRA, sedangkan di desa Bejijong juga dilakukan random sampling sebanyak 30 orang untuk mendapat perlakuan RRA.

Populasi dalam penelitian ini terdiri dari populasi target dan populasi terjangkau. Populasi target adalah populasi yang menjadi sasaran keberlakuan kesimpulan penelitian. Populasi target pada penelitian ini adalah perajin bata ibu rumah tangga yang ada di KecamatanTrowulan.

Populasi terjangkau (accessable population) adalah populasi yang secara riil dijadikan dasar dalam penentuan sampel, dan secara langsung menjadi lingkup sasaran keberlakuan kesimpulan. Populasi terjangkau adalah masyarakat yang berada di Kawasan Lindung Kecamatan Trowulan.

Pengambilan sampel dalam penelitian ini dilaksanakan secara multistage cluster random sampling atau pengambilan sampel cluster secara bertahap. Tahap pertama, random sampling akan dipilih secara administratif di wilayah Jawa Timur, wilayah yang terpilih adalah Mojokerto. Pada tahap kedua, Mojokerto terdiri dari sembilan kecamatan, dengan random sampling ditentukan satu kecamatan, yaitu Kecamatan Trowulan. Tahap ke tiga, dengan simple random sampling terpilih di Desa Sentonorejo dan Desa Bejijong 60 orang penduduk sebagai sampel.

Teknik Pengumpulan Data

Dari hasil pengumpulan data uji coba dan perhitungannya terhadap instrumen non-tes Partisipasi Masyarakat dalam pelestarian Kawasan Lindung Trowulan, perhitungan Validitasnya dapat dilihat pada Lampiran. Melalui perhitungan korelasi butir-butir (besaran $\mathrm{r}_{\mathrm{xy}}$ ) dan dibandingkan dengan $\mathrm{r}$ kritis (Product Moment), jika r-hitung $\geq$ r-tabel, maka butir 8, 9, 23, dan 25 dinyatakan drop. Dalam tabel harga r-kritis $0,561(\mathrm{n}=20, \alpha 0,01)$ terdapat 4 (empat) butir yang dinyatakan Drop, yaitu butir nomor 8, 9, 23, dan 25. Sedangkan dari perhitungan reliabilitasnya terhadap butir-butir yang valid, melalui nilai koefisien dengan Alpha Cronbach, diperoleh nilai 0,92661 . Dengan angka ini dapat dinyatakan

\begin{tabular}{|l|l|l|l|}
\hline Volume XI & Nomor 02 & Maret 2010 & ISSN 1411-1829 \\
\hline
\end{tabular}


bahwa butir-butirnya mempunyai keterandalan cukup tinggi.

Sementara itu pada instrumen pemahaman budaya, berdasarkan hasil pengumpulan data uji coba dan perhitungannya, validitas dengan Indeks Korelasi Biserial (korelasi point biserial $\geq 0,526$ dengan $\mathrm{n}=20$ pada $\alpha 0,01)$ dapat diketahui terdapat 4 butir soal yang drop, yaitu butir nomor 5, 10, 21, 27. Hal ini menjadikan jumlah butir yang layak untuk digunakan dalam menjaring data adalah sebanyak 31 butir soal.

Reliabilitas tes dari instrumen pemahaman sistem nilai budaya, dari hasil pemasukan dan perhitungan data dengan menggunakan rumus K-R 20, tentang koefisien reliabilitas tes. Maka seperti tertulis pada lampiran 7 didapat harga-harga $\Sigma$ pq $=$ 4,55 $\mathrm{k}=27$ dan $\mathrm{St}^{2}=11,9$ maka koefisien keterandalan instrumen tes 0,641 sehingga dapat dikatakan mempunyai reliabilitas yang cukup.

\section{Teknis analisis Data}

Analisis data yang digunakan dalam penelitian ini terdiri atas dua bagian, yaitu analisis deskriptif dan analisis diferensial. Analisis deskriptif dilakukan dengan penyajian data melalui tabel distribusi frekuensi, histogram, rata-rata dan simpangan baku. Sedangkan pada analisis diferensial digunakan pada pengujian hipotesis statistik.

Sebelum dilakukan pengujian hipotesis, kelompok-kelompok data dilakukan pengujian normalitas dan homogenitas. Untuk uji normalitas digunakan uji Liliefors dan uji homogenitas digunakan uji Bartlett. Pengujian hipotesis statistik digunakan ANAVA (analisis varians) dengan membanding angka $F_{\text {hitung }}$ dengan $F_{\text {tabel }}$ pada setiap faktor perlakuan (A dan B), dan interaksi antar faktor (A $\mathrm{x}$ B). Teknik analisis data untuk menguji perbedaan adalah teknik ANAVA dan jika terbukti bermakna akan dilanjutkan dengan uji Tuckey.

\section{HASIL PENELITIAN DAN PEMBAHASAN}

\section{Deskripsi Data}

Penelitian ini dilaksanakan di Kawasan Lindung Trowulan yang secara administratif termasuk ke dalam Kecamatan Trowulan, Kabupaten Mojokerto, Provinsi Jawa Timur. Di kawasan ini terdapat situs purbakala yang diduga bekas pusat kota Majapahit (town site). Sebagai warisan budaya, peninggalanpeninggalan arkeologis yang terletak di kawasan ini tentu tak dapat diabaikan nilai kulturalnya. Keberadaannya tidak saja memperteguh jatidiri bangsa tetapi juga amat penting dalam upaya peningkatan kualitas hidup masyarakat.

Namun di sisi lain warisan budaya yang luar biasa tersebut belum memperoleh penghargaan yang semestinya dari penduduk yang berdiam di kawasan tersebut. Penggalian lahan sawah selain untuk memperoleh bahan baku bata merah juga dapat diperoleh manfaat lain. Manfaat itu yakni bila ditemukan sisa-sisa tumpukan bata kuno - baik yang masih berupa pondasi maupun serakan - maka bata tersebut sering dimanfaatkan kembali untuk membangun pagar atau bahkan tembok rumah tinggal. Sementara itu bata yang sudah tidak utuh juga masih dapat dimanfaatkan sebagai bahan pengganti semen setelah melalui proses penumbukan (penghalusan). Bahan yang oleh masyarakat setempat dikenal sebagai semen merah ternyata mempunyai daya rekat yang cukup baik. Karena itu tidak mengherankan jika perburuan bata kuno melalui eksploitasi lahan kerapkali berlangsung. Kegiatan ini sudah berlangsung sejak sekitar tahun 1970an. Pada umumnya kerusakan pada Kawasan Lindung yang mengandung peninggalan arkelogis ini disebabkan dua faktor yakni alam dan manusia. Kerusakan karena faktor alam antara lain disebabkan karena proses penuaan secara alami. Bagaimanapun peninggalan arkeologis mempunyai masa yang terbatas dan secara alami mengalami pelapukan dan penurunan daya tahan. Sementara itu kerusakan yang disebabkan faktor manusia nampak dari terus meningkatnya eksploitasi lahan untuk memperoleh bahan baku juga terus mengalami peningkatan. Tercatat sekitar tiga ribuan industri pembuatan bata merah didirikan di kawasan ini. Beberapa lokasi penggalian bahan baku bata bahkan berada pada tidak jauh dari candi yang telah dilindungi Undang-undang Benda Kawasan Lindung. Sebagai contoh di Candi Wringin Lawang lokasi produksi bata hanya berjarak sekitar 100 meter dari lokasi candi. Di antara Candi Brahu dan candi Gentong juga terdapat beberapa lokasi produksi bata.

Lokasi-lokasi produksi tersebut seharusnya mendapat perlindungan sebagaimana diamanatkan UU No. 5/1992 tentang Benda Kawasan Lindung. Pada kenyataannya masih terdapat struktur bangunan kuno yang juga turut rusak akibat proses penggalian bahan baku bata. Bagi masyarakat setempat rusaknya Kawasan Lindung Trowulan tidak mudah untuk dipahami. Kekurangpahaman akan pemahaman sistem nilai budaya yang terkandung pada peninggalan arkeologis itu merupakan hal yang umum dijumpai di kalangan masyarakat yang tinggal di kawasan itu. Gambaran situasi ini membawa kepada asumsi bahwa upaya pelestarian Kawasan Lindung Trowulan juga mencakup aspek perilaku masyarakat yang dibentuk oleh situasi ekonomi dan lingkungan. Upaya pelestarian pada dasarnya memberi makna baru dan dalam masyarakat yang pluralistik, pemberian makna tersebut dapat beragam.

\section{Volume XI \\ Nomor 02


Maka, pelestarian warisan budaya - seperti terdapat di Kawasan Lindung Trowulan - harus dapat dibicarakan bersama, dinegosiasikan, dan perlu disepakati bersama pula lewat dialog yang terbuka, partisipatif dan seimbang.

Tabel 1: Data tingkat partisipasi masyarakat dalam pelestarian Kawasan Lindung Trowula

\begin{tabular}{|c|c|c|c|c|}
\hline \multirow{2}{*}{ Pexlakuan } & \multicolumn{2}{|c|}{$\begin{array}{c}\text { Strategi Pemecahan Masalah } \\
\text { PRA }\end{array}$} & \multicolumn{2}{c|}{$\begin{array}{c}\text { Strategi Pemecahan Masalah } \\
\text { RRA }\end{array}$} \\
\cline { 2 - 5 } & $\begin{array}{c}\text { Pemahaman } \\
\text { budaya Tinggi }\end{array}$ & $\begin{array}{c}\text { Pemahaman } \\
\text { budaya Rendah }\end{array}$ & $\begin{array}{c}\text { Pemahaman } \\
\text { budaya Tinggi }\end{array}$ & $\begin{array}{c}\text { Pemahaman } \\
\text { budaya Rendah }\end{array}$ \\
\hline 1 & & & & \\
2 & & & 56 & 80 \\
3 & 70 & 73 & 59 & 72 \\
4 & 79 & 74 & 69 & 70 \\
5 & 85 & 60 & 62 & 72 \\
6 & 70 & 52 & 60 & 67 \\
7 & 72 & 69 & 55 & 74 \\
8 & 75 & 67 & 72 & 74 \\
9 & 80 & 63 & 60 & 70 \\
10 & 69 & 65 & 48 & 69 \\
11 & 68 & 55 & 55 & 65 \\
12 & 83 & 51 & 50 & 62 \\
13 & 78 & 56 & 53 & 61 \\
\hline
\end{tabular}

Sumber : diolah dari data primer Pengujian Hipotesis dan Pembahasan

Setelah dilakukan analisis varians (ANAVA) melalui uji $\mathrm{F}$, maka diperoleh hasil perhitungan untuk masing-masing hipotesis adalah sebagai berikut:

1. Hipotesis nol $\left(\mathrm{H}_{0}\right)$, untuk : Strategi pemecahan masalah PRA dan strategi pemecahan masalah RRA tidak mempengaruhi partisipasi masyarakat dalam pelestarian Kawasan Lindung Trowulan, ditolak.

Dari hasil perhitungan ANAVA, setelah variansi antar kolom (strategi pemecahan masalah) dibagi variansi di dalam kelompok didapat nilai $\mathrm{F}=$ 7,54 dan bila dibandingkan dengan $\mathrm{F}$ tabel $(0,01)$ sebesar 7,159, maka $\mathrm{F}$ hitung $<\mathrm{F}$ tabel sehingga hipotesis nol ditolak. Hal ini berarti hipotesis bahwa strategi pemecahan masalah dengan PRA lebih baik dibandingkan dengan strategi pemecahan masalah dengan RRA terhadap pelestarian Kawasan Lindung Trowulan, diterima.

Dengan demikian hasil penelitiannya adalah partisipasi masyarakat dalam pelestarian Kawasan Lindung Trowulan dengan strategi pemecahan masalah PRA lebih baik dibandingkan dengan strategi pemecahan masalah RRA.
2. Hipotesis nol $\left(\mathrm{H}_{\mathrm{o}}\right)$, untuk: faktor pemahaman budaya tinggi tidak mempengaruhi partisipasi masyarakat dalam pelestarian Kawasan Lindung Trowulan dengan strategi RRA dibandingkan strategi PRA, diterima, diterima.

Dari hasil perhitungan ANAVA, setelah variansi antar kolom (pemahaman sistem budaya) dibagi variansi di dalam kelompok didapat nilai $\mathrm{F}=$ 0,86 dan bila dibandingkan dengan $\mathrm{F}$ tabel $(0,05)$ sebesar 4,030, maka $F$ hitung $<F$ tabel sehingga hipotesis nol diterima.

Hal ini berarti hipotesis bahwa pada masyarakat dengan kelompok yang mempunyai pemahaman budaya tinggi dengan perlakuan strategi pemecahan masalah RRA dibandingkan dengan strategi pemecahan PRA terhadap partisipasi masyarakat dalam pelestarian Kawasan Lindung Trowulan tidak menunjukkan adanya perbedaan

\begin{tabular}{|l|c|c|c|}
\hline Volume XI & Nomor 02 & Maret 2010 & ISSN 1411-1829 \\
\hline
\end{tabular}


3. Hipotesis nol $\left(\mathrm{H}_{0}\right)$, untuk: faktor pemahaman budaya rendah tidak mempengaruhi partisipasi masyarakat dalam pelestarian Kawasan Lindung Trowulan dengan strategi RRA dibandingkan strategi PRA, diterima.

Dari hasil perhitungan ANAVA, setelah variansi antar kolom (Faktor tingkat pemahaman budaya) dibagi variansi di dalam kelompok didapat nilai $\mathrm{F}=0,86$ dan bila dibandingkan dengan $\mathrm{F}$ tabel $(0,05)$ sebesar 4.030 maka $F_{\text {hitung }}<\mathrm{F}_{\text {tabel }}$ sehingga hipotesis nol diterima.

Hal ini berarti hipotesis bahwa pada masyarakat dengan kelompok yang mempunyai pemahaman budaya rendah dengan perlakuan strategi pemecahan masalah RRA dibandingkan dengan strategi pemecahan PRA terhadap partisipasi masyarakat dalam pelestarian Kawasan Lindung Trowulan tidak menunjukkan adanya perbedaan.
4. Hipotesis nol $\left(\mathrm{H}_{0}\right)$ : Tidak terdapat interaksi antara faktor strategi pemecahan masalah dan faktor tingkat pemahaman budaya terhadap partisipasi masyarakat dalam pelestarian Kawasan Lindung Trowulan, ditolak.

Dari hasil perhitungan ANAVA, setelah variansi interaksi antar kelompok (Faktor strategi pemecahan masalah dan faktor pemahaman sistem nilai budaya) dibagi variansi di dalam kelompok didapat nilai $\mathrm{F}=46,84$ dan bila dibandingkan dengan $F_{\text {tabel }}(0,01)$ sebesar 7,159, maka $F_{\text {hitung }}>F$ tabel sehingga hipotesis nol ditolak.

Hal ini berarti hipotesis bahwa faktor strategi pemecahan masalah dan faktor pemahaman budaya merupakan faktor yang saling mempengaruhi terhadap partisipasi masyarakat dalam pelestarian Kawasan Lindung Trowulan, diterima (H1: INT A $\mathrm{X} \mathrm{B} \neq 0$ ).

Tabel 2 : Rangkungan hasil perhitungan ANAVA 2x2

\begin{tabular}{|c|c|c|c|c|c|c|c|}
\hline \multirow{2}{*}{$\begin{array}{l}\text { Sumber } \\
\text { Varians }\end{array}$} & \multirow{2}{*}{ dk } & \multirow{2}{*}{ JK } & \multirow{2}{*}{ RJK } & \multirow{2}{*}{\multicolumn{2}{|c|}{$\begin{array}{c}\text { F } \\
\text { hitung }\end{array}$}} & \multicolumn{2}{|c|}{ F tabel } \\
\hline & & & & & & $\alpha=0.05$ & $\alpha=0.01$ \\
\hline $\begin{array}{l}\text { Antar } \\
\text { kelompok } \\
\text { Dalam } \\
\text { kelompok }\end{array}$ & $\begin{array}{r}3 \\
48\end{array}$ & $\begin{array}{l}2.381,00 \\
2.068,77\end{array}$ & $\begin{array}{r}793,67 \\
43,10\end{array}$ & 18,41 & $* *$ & 2,798 & 4,218 \\
\hline $\begin{array}{l}\text { Strategi } \\
\text { (Kolom) } \\
\text { Pemahaman } \\
\text { budaya } \\
\text { (Baris) }\end{array}$ & $\begin{array}{l}1 \\
1 \\
1\end{array}$ & 325,00 & $\begin{array}{l}325,00 \\
37,23\end{array}$ & $\begin{array}{l}7,54 \\
0,86\end{array}$ & $\begin{array}{l}* * \\
\mathrm{~ns}\end{array}$ & 4,030 & 7,159 \\
\hline Interaksi & 1 & $2.018,77$ & $2.018,77$ & 46,84 & $* *$ & & \\
\hline Jumlah & 51 & $4.449,77$ & & & & & \\
\hline
\end{tabular}

Keterangan:
** = Sangat Signifikan
* = Signifikan
ns $=$ Nonsignifikan

\begin{tabular}{|l|l|l|l|}
\hline Volume XI & Nomor 02 & Maret 2010 & ISSN 1411-1829 \\
\hline
\end{tabular}


Dengan demikian hasil penelitiannya adalah: terdapat interaksi yang nyata antara faktor strategi pemecahan masalah dan faktor pemahaman budaya terhadap partisipasi masyarakat dalam pelestarian Kawasan Lindung Trowulan. Visualisasi dari interaksi tersebut dapat dilihat pada Gambar berikut ini.

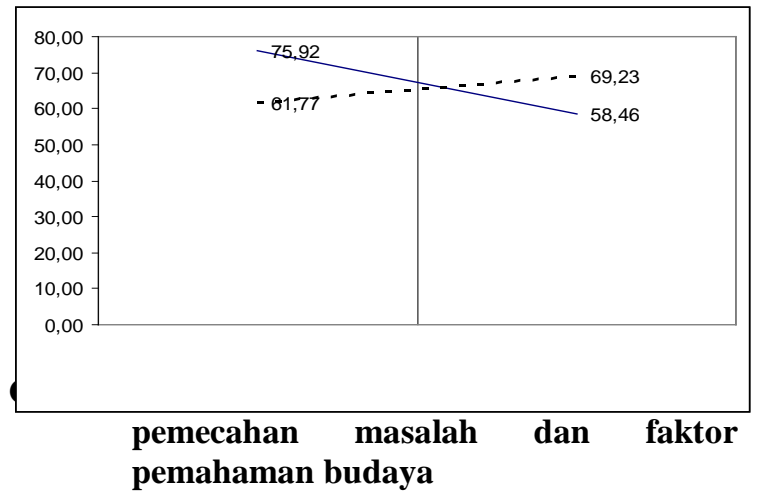

Untuk itu, karena adanya interaksi maka dilanjutkan dengan tingkat kebermaknaan interaksi antarvariabel, melalui uji Tukey diperoleh interaksi yang bermakna terjadi pada interaksi antara faktor strategi pemecahan masalah dengan tingkat pemahaman budaya tinggi (A1B1dan A2B1).

Hasil uji Tukey menunjukkan bahwa pola interaksi antara faktor terjadi pada interaksi antara strategi pemecahan masalah dengan PRA dan RRA pada kelompok masyarakat yang mempunyai tingkat nilai budaya tinggi Qhitung 9,59 > 4,817 $Q_{\text {tabel }}$ pada tingkat ketelitian

interaksi antara strategi pemecahan masalah PRA dengan strategi RRA pada kelompok masyarakat yang mempunyai tingkat pemahaman budaya rendah Qhitung 4,1 $<4,817$ Qtabel pada tingkat ketelitian perbedaan.

Dari seluruh kajian di atas, bahwa keempat rumusan masalah, hipotesis statistik dan pengujiannya, terutama yang berkaitan dengan ketidak-sesuaian antara hipotesis dan hasil penelitian, maka pembahasannya adalah sebagai berikut:

Partisipasi masyarakat dalam pelestarian Kawasan Lindung Trowulan dengan strategi pemecahan masalah PRA dan RRA tidak menunjukkan perbedaan pada kelompok masyarakat yang mempunyai pemahaman budaya tinggi maupun pada kelompok masyarakat yang mempunyai pemahaman budaya rendah

Pemahaman budaya sebagai variabel atribut dalam penelitian ini, walaupun secara teoretis dapat mempengaruhi faktor perlakuan dalam pembentukan karakter partisipasi terhadap pelestarian Kawasan Lindung Trowulan, namun penelitian ini tidak menunjukkan perbedaan. Hal ini banyak disebabkan oleh pengaruh perbedaan skor pemahaman budaya yang tidak kontras antara masyarakat yang mempunyai pemahaman budaya tinggi dengan masyarakat yang mempunyai pemahaman budaya rendah.

\section{Keterbatasan Penelitian}

Perlu disadari bahwa, walaupun perencanaan penelitian eksperimen ini telah dirancang sedemikian rupa untuk menghasilkan yang optimal, namun pada pelaksanaannya tidak luput dari keterbatasan dan kelemahan, baik dalam metodologi seperti yang sudah tertuang di bab terdahulu, juga memiliki keterbatasan sebagai berikut:

1. Kegiatan perlakuan hanya dilakukan satu periode, sehingga perbedaan pencapaian partisipasi tidak nampak jelas. Hal ini disebabkan oleh keterbatasan sumber daya yang dimiliki oleh peneliti, terutama tuntutan waktu dalam tahapan eksperimen

dan kesempatan waktu pelaksanaan dengan tingkat kesempatan masyarakat yang terbatas dalam mengikuti prosedur penelitian.

2. Implementasi strategi pemecahan masalah dalam pelaksanaannya memiliki banyak kendala, terutama sekali dalam merancang suatu = 0,01ransandgan k kerja bersama masyarakat, namun tetap diperlukan "Term of Reference" yang terukur dan memiliki kekuatan baku dalam pelaksanaannya. Keterbatasan inilah yang menjadi kendala dalam pelaksanaan penelitian. Hal ini berdampak pada pola pengaturan dan pengorganisasian masyarakat sebagai sampel dan subjek dalam program pemecahan masalah ini, kesiapan jumlah fasilitator tidak mencukupi sehingga keterlibatan masyarakat untuk memenuhi seluruh prosedur penelitian tidak optimal.

\section{KESIMPULAN, IMPLIKASI DAN SARAN}

\section{Kesimpulan}

Berdasarkan hasil pengujian hipotesis, maka temuan yang diperoleh adalah sebagai berikut:

1. Terdapat perbedaan partisipasi masyarakat dalam pelestarian Kawasan Lindung Trowulan

\begin{tabular}{|l|l|l|l|}
\hline Volume XI & Nomor 02 & Maret 2010 & ISSN 1411-1829 \\
\hline
\end{tabular}


antara perlakukan strategi pemecahan masalah PRA dengan perlakukan strategi pemecahan masalah RRA. Hal tersebut ditunjukkan dari hasil analisis data yang menunjukkan $\mathrm{F}_{\text {hit }}$ lebih kecil $F_{\text {tab }}\left(7,159<7,54_{\alpha=0,01}\right)$.

2. Pada kelompok masyarakat yang mempunyai tingkat pemahaman budaya tinggi, partipasi dalam pelestarian Kawasan Lindung Trowulan antara perlakuan strategi pemecahan masalah PRA dengan perlakukan strategi pemecahan masalah RRA tidak signifikan. Dari hasil analisis data didapat $\mathrm{F}_{\text {hit }}$ lebih kecil $\mathrm{F}_{\text {tab }}(0,86<$

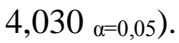

3. Pada kelompok masyarakat yang mempunyai tingkat pemahaman budaya rendah, partisipasi dalam pelestarian Kawasan Lindung Trowulan antara perlakuan strategi pemecahan masalah RRA dibandingkan dengan perlakukan strategi pemecahan masalah PRA tidak signifikan. Dari hasil analisis data didapat $F_{\text {hit }}$ lebih kecil $F$ tab $\left(0,86<4,83_{\alpha=0,05}\right)$.

4. Terdapat interaksi antara faktor strategi pemecahan masalah dengan faktor tingkat pemahaman budaya terhadap partisipasi masyarakat dalam pelestarian Kawasan Lindung Trowulan. Dari hasil analisis data didapat $F_{\text {hit }}$ lebih besar $\mathrm{F}_{\text {tab }}\left(46,84>7,159_{\alpha=0,05}\right)$.

Berdasarkan temuan-temuan tersebut maka dapat disimpulkan terdapat interaksi posistif antara faktor strategi pemecahan masalah dan faktor tingkat pemahaman budaya terhadap partisipasi masyarakat dalam pelestarian Kawasan Lindung Trowulan, pada masyarakat yang memiliki pemahaman budaya tinggi partisipasinya lebih baik. Hal ini menunjukkan bahwa dalam pencapaian partisipasi masyarakat pelestarian Kawasan Lindung Trowulan dapat dilakukan strategi pemecahan masalah yang sesuai dengan mempertimbangkan tingkat pemahaman sistem nilai budaya di masyarakat.

\section{Implikasi}

Berdasarkan uraian kesimpulan di atas, maka dapat dijelaskan implikasi dari penelitian ini adalah sebagai berikut:

Pertama, terdapat perbedaan antara strategi pemecahan masalah yang dilakukan melalui metode PRA dengan strategi pemecahan masalah yang dilakukan melalui metode RRA. Metode PRA terbukti lebih tepat digunakan dalam menyelesaikan masalah lingkungan sosial di perdesaan ketimbang metode RRA.

Kedua, jika melihat perbedaan tersebut maka sebagai konsekuensinya keterlibatan masyarakat dalam menyelesaikan persoalannya sendiri perlu lebih ditingkatkan, meski lebih menyita waktu namun persepsi yang sama antarwarga masyarakat dapat

diwujudkan. Hal ini mengingat keterlibatan mereka sejak perencanaan, pelaksanaan, monitoring, hingga evaluasi.

Ketiga, sementara itu metode RRA yang diajukan sebagai alternatif memang dapat lebih cepat diterapkan dalam memecahkan masalah, namun keterlibatan masyarakat sebagaimana terdapat pada PRA tidak dapat diwujudkan karena semua tahap pelaksanaan dilakukan team ahli.

\section{Saran}

Beberapa saran yang diajukan di sini tertuju pada beberapa pihak. Pertama, untuk kepala daerah misalnya Bupati Mojokerto ada baiknya Pemerintah Daerah Kabupaten Mojokerto segera menyediakan alternatif lapangan kerja yang lain terhadap petani di Trowulan agar aktifitas mereka yang selama ini membuat bata dapat berpindah ke mata pencaharian yang baru sehingga tidak seterusnya melakukan perusakan lingkungan di kawasan lindung tersebut. Kedua, untuk Kepala Balai Pelestarian Peninggalan Purbakala Jawa Timur, disarankan untuk melaksanakan kegiatan sosialisasi kepada masyarakat desa di Trowulan berkaitan dengan pentingnya pelestarian peninggalan purbakala bagi kemajuan peradaban bangsa, khususnya mereka yang tinggal di Kawasan Trowulan. Ketiga, untuk Kepala Suku Dinas Kebudayaan Dinas Pariwisata Mojokerto Perlu hendaknya melakukan upaya pendampingan bagi penduduk Trowulan dalam mengembangkan pariwisata lewat penggalian potensi-potensi budaya di kawasan tersebut. Keempat, untuk Kepala Desa agar lebih mendorong peran penduduk dalam mengendalikan kawasan lindung Trowulan agar kerusakan tidak terjadi lebih parah dan sebaiknya penduduk juga diposisikan di garis depan, sehingga dapat memantau dan memberi informasi lebih cepat kepada pihak berwenang. Kelima, bagi para perajin. perlu diberikan dorongan agar lebih kreatif dalam membuat karya-karya yang memiliki kekhasan Trowulan sehingga memiliki nilai jual yang kompetitif dengan produk kawasan lain.

\section{DAFTAR PUSTAKA}

Allan, D.L , et al, Statement of Soil Quality. Agronomy News: June; 7, 1995

Alisjahbana, Sutan Takdir. Persepsi Masyarakat tentang Kebudayaan. Jakarta: Gramedia, 1985.

\section{Volume XI \\ Nomor 02 \\ Maret 2010 \\ ISSN 1411-1829}


Anon, The Burra Charter. Sydney: Australia National Committee for ICOMOS, 1979.

Bachtiar, Harsja W. "Integrasi Nasional Indonesia” dalam Wawasan Kebangsaaan. Jakarta: Bakom PKB Pusat, 1984.

Barrow, C.J, Developing the Environment: Problems and Management.New York: Longman Group, 1995.

Borg, Walter D, and Meredith D Gall., Educational research, an introduction. 4 th Ed. New York: Longman, 1983

Braun R, Ann., Beyond the Problem-Solving Approach to Sustainable Rural Development dalam http:/www.idrc.ca/en/ev-85059-201-1DO_TOPIC

Chambers, Robert, "The Origins and Practice of Participatory Rural Appraisal”, dalam World Development 22 (7), 1991

Chambers, Robert, Rural Appraisal: Rapid, Relaxed and Participatory. Sussex: IDS Discussion Paper 311, 1992.

Chohan, John, M and Norman T Uphoff, Rural Development Participation: concept and measures for project design, implementation and evaluation. New York: Cornell University Press, 1977.

Daniel, Moehar, dkk PRA Participatory Rural Appraisal, Jakarta: Bumi Aksara, 2006.

Davis, Keith, Human Behavior at Work: Organizational Behavior. New York; McGraw-Hill Series in Management., 1979.

Doyle, Rebekah and Marianne Krasny, Participatory Rural Appraisal as an Approach to Environmental Education dalam http://www. gardenmosaic.cornell.edu

Hadi, Sudharto P. Aspek Sosial AMDAL: Sejarah, Teori dan Metode. Yogyakarta: Gadjah Mada University Press, 2002.

Haeruman, Herman. "Pengelolaan Sumber Daya Alam dan Lingkungan Hidup dalam Usaha Peningkatan Kualitas Hidup Jangka Panjang” dalam Manusia dalam Keserasian Lingkungan (penyunting: Mohamad Soerjani dan Bahrin Samad), Jakarta: Lembaga Penerbit Fakultas Ekonomi Universitas Indonesia, 1983.

Hardjasoemantri, Koesnadi. Hukum Tata Lingkungan. Yogyakarta: Gadjah Mada University Press, 1997.
Ife, Jim dan Frank Tesoriero, Community Development: community based alternatives in an Age of Globalization. New South Wales: Pearson Education, 2008.

Kistanto, Nurdien H. Dari Pemahaman Ke Penyertaan dan Pember-dayaan: Suatu Perkembangan Metodologi dalam Kajian \& Tindakan di Bidang Sosial Budaya, Semarang: Universitas Diponegoro, 2003.

Koentjaraningrat, Kebudayaan, Mentalitas dan Pembangunan. Jakarta: Gramedia Pustaka Utama, 2002.

Krathwohl, David R., Bloom, Benjamin S, and Masia, Bertram B,.Taxonomy of educational objectives, Book 1 cognitive domain, New York: Longman, 1956

Kroeber A.L. and Clyde Kluckhohn. Culture: A Critical Review of Concept and Definitions .Cambridge: Peabody Museum, 1952.

McNeely, Jeffrey A., Economics and Biological Diversity, (Switzerland: International Union for Conser-vation of Nature and Natural Resources), 1988

Melalatoa, M. Junus. Sistem Budaya Indonesia. Jakarta: Pamator, 1997

Mikkelsen, Britha. Metode Penelitian Partisipasi dan Upaya-upaya Pemberdayaan, diterjemahkan Matheos Nalle. Jakarta: Yayasan Obor Indonesia. 2001.

Mitzberg, Henry and Quinn James Brian. The Strategy Process: Concept and Context. New York: Prentice Hall, Inc, Simon and Schuster Co., 1992.

Mundardjito, Bukti-bukti Kejayaan Majapahit Muncul Kembali . Jakarta: Proyek Pemugaran dan Pemeliharaan Peninggalan Sejarah dan Purbakala, 1986.

--------, Pendekatan Studi Permuki-man Sebagai Strategi Kegiatan Arkeologi Terpadu. Depok: Fakultas Ilmu Pengetahuan Budaya Universitas Indonesia, 2003.

---------, “Pelestarian Sumberdaya Budaya Maritim”. Makalah yang disampaikan dalam Seminar Eksplorasi Sumberdaya Maritim Indonesia di Pusat Studi Jepang, Universitas Indonesia. 2005.

Owen, OS, Natural Research Conser-vation on Ecological Approach, Ed. 4, New York: Mac Millan Publishing, 1985. 
Parillo N Vincent, Contemporary Social Problems. New York: John Wiley and Son, 1997.

Purba, Jonny, Pengelolaan Lingkungan Sosial. Jakarta: Yayasan Obor Indonesia, 2002.

Rambo,Terry A. Conceptual Approach to Human Ecology, Research Report No. 14. Honolulu: Hawaai: East-West Environment and Policy Institute, 1983).

Raab, Eral and Gertude Jaeger Seiznik, Major Social Problems. New York: Harper and Row Publisher, 1994.

Ramos, Roman, Community Participation Model. Canada : International Development Research Center, 1986.

Sastropoetro, S.R.A, Partisipasi Komuni-kasi, Persuasi dan Disiplin dalam Pembangunan Nasional. Ban-dung : Alumni, 1995.

Sedyawati, Edi, "Pelestarian Seni Tradisi dalam Program Pemerintah”, dalam Kumpulan Makalah dan Sambutan .Jakarta : Dirjen Kebudayaan, 1999.

Sharer, Robert J. and Wendy Ashmore, Fundamentals of Archaeology. California: The Benjamin / Cummings Publishing Company, 1980.

Soerjani, Mohamad, Rofiq Ahmad dan Rozy Munir., Lingkungan: Sumberdaya Alam dan Kependudukan dalam Pemba-ngunan. Jakarta: UI Press, 1987.

Soerjani, Mohamad, Pembangunan dan Lingkungan: Meniti Gagasan dan Pelaksanaan Sustainable Deve-lopment, Jakarta: Institut Pendidikan dan Pengembangan Lingkungan, 1997.

---------, Ekologi Manusia, Jakarta: Pusat Penerbitan Universitas Terbuka, 2002

---------, “Lingkungan Hidup, Pengelolaan dan Pemanfaatan dalam Pembangunan”, makalah Pelatihan AMDAL PT. Komatsu : Indonesia Tbk 25 Februari 2005, Jakarta: PT. KOMATSU, 2005 (tidak diterbitkan).

Soerjani, Mohamad, Arief Yuwono, dan Dedi Fardiaz, Lingkungan Hidup (The Living Environment), Jakarta: IPPL dan Restu Agung, 2006.

Steward, Julian H., Theory of Culture Change, (Urbana: University of Illinois Press, 1982),
Suharto, Edi, Membangun Masyarakat Memberdayakan Rakyat, Bandung: Refika Aditama, 2005.

Sumarto, Hetifah Sj. Inovasi, Partisipasi dan Good Governance: 20 Prakarsa Inovatif dan Partisipatif di Indonesia, Jakarta: Yayasan Obor Indonesia, 2003.

Sutrisno, Lukman. Menuju Masyarakat Partisipatif. Yogyakarta: Kanisius, 1995.

Tanudirjo, Daud A., "Warisan Budaya Untuk Semua Arah Kebijakan Pengelolaan Warisan Budaya Indonesia Di Masa Datang”, dalam Kumpulan Makalah Kongres Kebudayaan V Di Bukittinggi. Jakarta : Dirjen Kebudayaan, 2003.

Tjandrasasmita, Uka, "Strategi Peles-tarian Benda Cagar Budaya: hubungannya dengan arkeologi”, makalah dalam Seminar Nasional Metodologi Riset Arkeologi. Depok: Jurusan Arkeologi Fakultas Sastra Universitas Indonesia, 1995

Tunggal, Arif Djohan, Peraturan Perundangundangan Lingkungan Hidup. Jakarta: Harvarindo, 2001.

Veeger, K.J., Realitas Sosial.Jakarta: Gramedia, 1986.

Yeung, Y.M. Participatory Urban Services in Asia. Canada: International Development Research Center, 1986.

\section{Volume XI \\ Nomor 02 \\ Maret 2010 \\ ISSN 1411-1829}

